\title{
Consensus Forecast of U.S. Energy Supply and Demand to the Year 2000
}

\author{
J. A. Lane
}

\section{OAK RIDGE NATIONAL LABORATORY}




\section{DISCLAIMER}

This report was prepared as an account of work sponsored by an agency of the United States Government. Neither the United States Government nor any agency Thereof, nor any of their employees, makes any warranty, express or implied, or assumes any legal liability or responsibility for the accuracy, completeness, or usefulness of any information, apparatus, product, or process disclosed, or represents that its use would not infringe privately owned rights. Reference herein to any specific commercial product, process, or service by trade name, trademark, manufacturer, or otherwise does not necessarily constitute or imply its endorsement, recommendation, or favoring by the United States Government or any agency thereof. The views and opinions of authors expressed herein do not necessarily state or reflect those of the United States Government or any agency thereof. 


\section{DISCLAIMER}

Portions of this document may be illegible in electronic image products. Images are produced from the best available original document. 


\section{Printed in the United States of America. Available from National Technical Information Service \\ U.S. Department of Commerce \\ 5285 Port Royal Road, Springfield, Virginia 22161 \\ Price: Printed Copy $\$ 4.00$; Microfiche $\$ 3.00$}

This report was prepared as an account of work sponsored by the United States Government. Neither the United States nor the Energy Research and Development Administration/United States Nuclear Regulatory Commission, nor any of their employees, nor any of their contractors, subcontractors, or their employees, makes any warranty, express or implied, or assumes any legal liability or responsibility for the accuracy, completeness or usefulness of any information, apparatus, product or process disclosed, or represents that its use would not infringe privately owned rights. 
ORNL/TM-5369

Dist. Category UC-80

Contract No. W-7405eng-26

PROGRAM PLANNING AND ANALYSIS

\section{Consensus Forecast of U.S. Energy Supply and Demand to the Year 2000}

J. A. Lane

Manuscript Completed - February 1976

Date Published - May 1977

This report was prepared as an account of work

sponsored by the United States Government. Neither the United States nor the Uniled states Energ Research and Development Ad ot thein, contractors, subcontmetors, of their employees, makes any warmanty, express or implied, or assumes any legal lisbility or responsibility for the accuracy, completeness or usefulness of any information, apparatu, product or

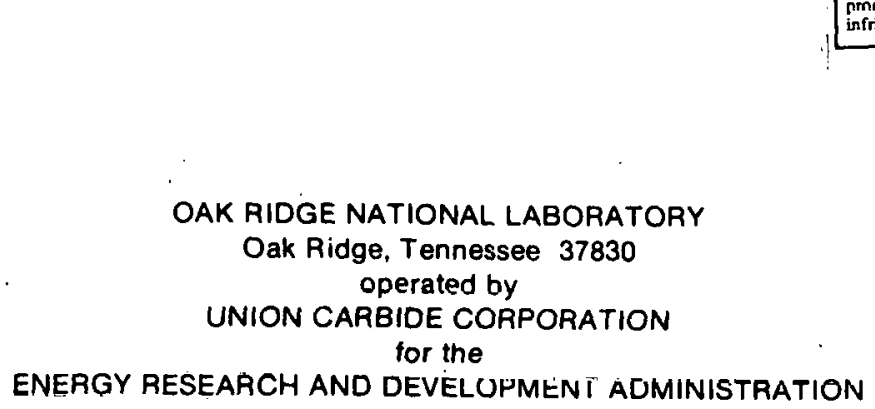

\footnotetext{
OAK RIDGE NATIONAL LABORATORY

Oak Ridge, Tennessee 37830 operated by UNION CARBIDE CORPORATION for the

ENERGY RESEARCH AND DEVELUPMENT ADMINISTRATION
} 


\section{THIS PAGE}

WAS INTENTIONALLY

LEFT BLANK 


\section{CONTENTS}

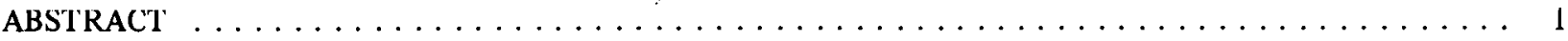

1. DESCRIPTION OF FORECAST METHODS $\ldots \ldots \ldots \ldots \ldots \ldots$

1.1 Methodology of Energy and Electricity Forecasting $\ldots \ldots \ldots \ldots \ldots$

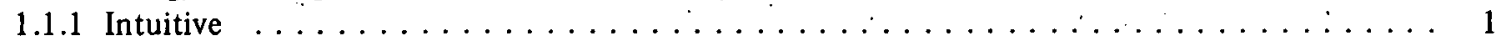

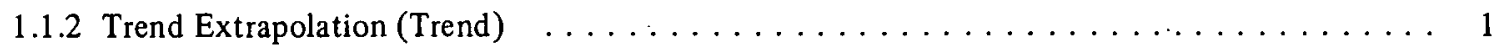

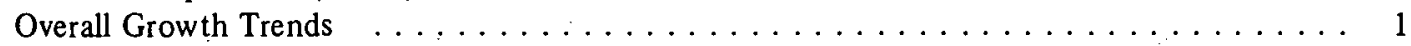

Per Capita and Population Growth Trends (Per Capita Trend) $\ldots \ldots \ldots \ldots \ldots \ldots$

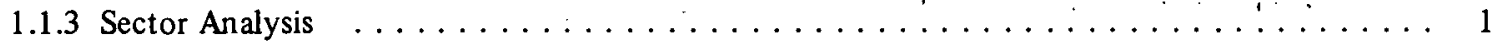

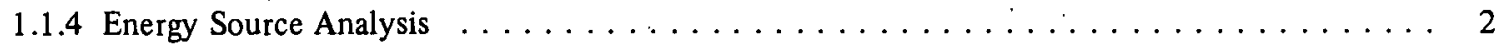

1.1 .5 Regression Analysis (Econometric Model) $\ldots \ldots \ldots \ldots \ldots \ldots \ldots \ldots \ldots$

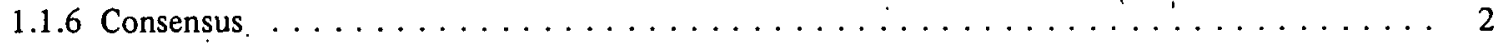

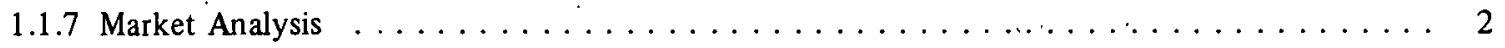

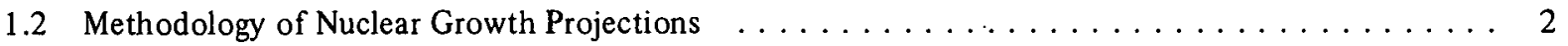

2. REVIEW AND ANALYSIS OF RECENT ENERGY FORECASTS . . . . . . . . . . . . . . 2

2.1 Associated Universities, Inc., Reference Energy Systems and Resource Data for Use in the Assessment of Energy Technologies PB-221 422 (also AET-8), May 1972 . . . . . . . . . 2

2.2 Intertechnology Corporation, The U.S. Energy Problem, for NSF-RANN, November 1972 . . . . 4

2.3 National Petroleum Council, Guide to NPC Report on U.S. Energy Outlook, December 1972 _ . . 4

2.4 W. G. Dupree and J. A. West, United States Energy Through the Year 2000, Department of the Interior, U. S. Government Printing Office, December $1972 \ldots \ldots \ldots$. . . . . . . . . . . 4

2.5 S. Field, Stanford Research Institute, "The U.S. Energy Puzzle," paper presented at 38th midyear meeting of Division of Refining, Philadelphia, May $1973 \ldots \ldots \ldots \ldots$

2.6 P. N. Ross, Westinghouse Electric Corporation, "The Nuclear Electric Economy," paper presented at the Conference on the Hydrogen Economy, Miami, Fla., March $1974 \ldots \ldots \ldots$

2.7 Joint Committee on Atomic Energy, Understanding the National Energy Dilemma,

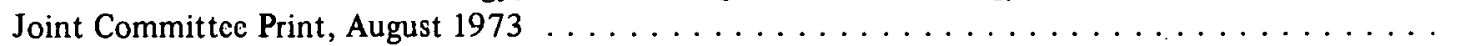

2.8 NASA/ASEE-Auburn University, Terrestrial Applications of Solar Technology and Research

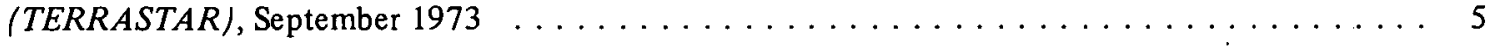

2.9 Environmental Protection Agency, Alternative Futures and Environmental Quality, Office of Research and Development November 1973

S. Atomic Energy Commission,

2.10 D. L. Kay, The Nation's Energy Future, WASH-1281, U.S. Atomic Energy Commission,

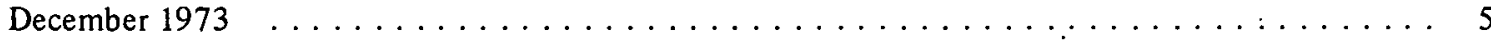

2.11 Ford Foundation, Exploring Energy Choices, prcliminary report of Energy Policy Project of thc Ford Foundation, early 1974

2.12 Office of Planning and Analysis, Nuclear Power Growth 1974-2000, WASTI-1 139(14), U.S. Atomic Energy Commission, February 1974 
2.13 L. T. Blank and R. K. Riley, "Future U.S. Demand Patterns and Use of Hydrogen," paper presented at the Conference on the Hydrogen Economy, Miami, Fla., March 1974 . . . . . . . 6

2.14 Council on Environmental Quality, A National Energy Conservation Program The Half and Half Plan, March $1974 \ldots \ldots \ldots \ldots \ldots \ldots \ldots \ldots \ldots \ldots$

2.15 National Petroleum Council, Energy Conservation in the United States - Short Term Potential, 1974-1978, March 1974

2.16 M. A. Adelman et al., "Energy Self Sufficiency, An Economic Viewpoint,"

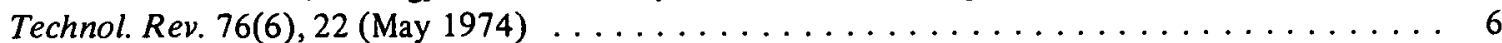

2.17 R. C. Seamans, U.S. Energy Prospects: An Engineering Viewpoint, National

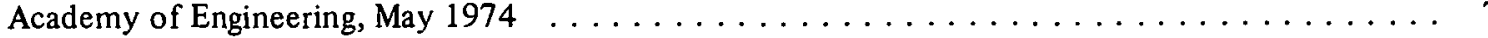

2.18 NASA/ASEE-Auburn University, MEGASTAR (The Meaning of Energy Growth: An Assessment of Systems, Technologies and Requirements), Report NASA/CR-120338, September 1974 . . . . 7

2.19 Federal Energy Administration, Project Independence Report, November 1974 . . . . . . . . . 7

2.20 Office of Planning and Analysis, Total Energy, Electric Energy and Nuclear Power Projections, United States, Energy Research and Development Administration, February $1975 \ldots \ldots \ldots \ldots$

2.21 E. Teller, Energy - A Plan for Action, report to the Energy Panel of the Commission on Critical Choices for Americans, April $1975 \ldots \ldots \ldots \ldots \ldots \ldots \ldots \ldots \ldots \ldots \ldots$

3. ENERGY CONSUMPTION BY SOURCE $\ldots \ldots \ldots \ldots \ldots \ldots \ldots \ldots \ldots \ldots \ldots \ldots$

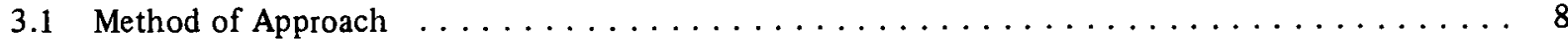

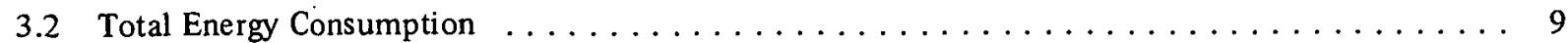

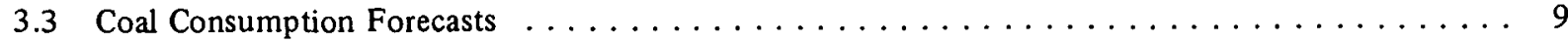

3.4 Domestic Natural Gas Production $\ldots \ldots \ldots \ldots \ldots \ldots \ldots \ldots \ldots \ldots \ldots \ldots \ldots \ldots$

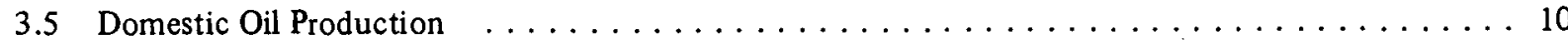

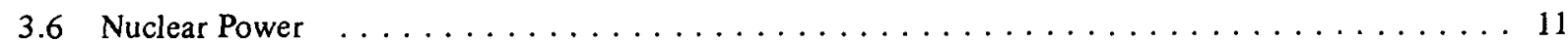

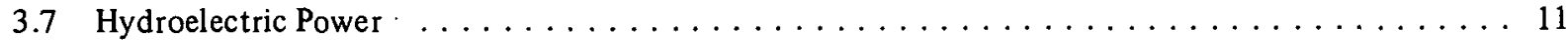

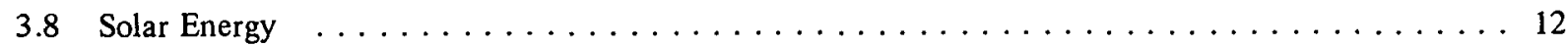

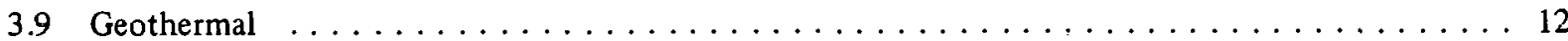

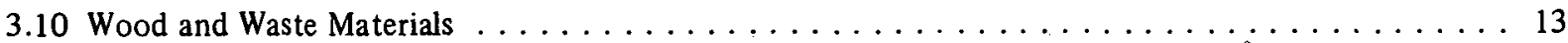

3.11 Summary of U.S. Energy Consumption by Source $\ldots \ldots \ldots \ldots \ldots \ldots \ldots \ldots \ldots \ldots$

4. ENERGY USE BY CONSUMING SECTOR $\ldots \ldots \ldots \ldots \ldots \ldots \ldots \ldots \ldots \ldots \ldots \ldots \ldots$

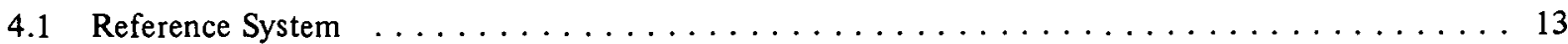

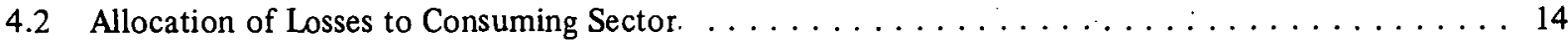

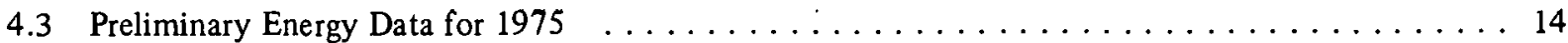

4.4 Forecast of Energy Consumption by Sector - Year $1985 \ldots \ldots \ldots \ldots \ldots \ldots \ldots \ldots \ldots$

4.5 Year 2000 Energy Consumption by Consuming Sector and Source $\ldots \ldots \ldots \ldots \ldots \ldots \ldots \ldots$

5. SUMMARY OF U.S. ENERGY RESOURCES $\ldots \ldots \ldots \ldots \ldots \ldots \ldots \ldots \ldots \ldots \ldots \ldots$

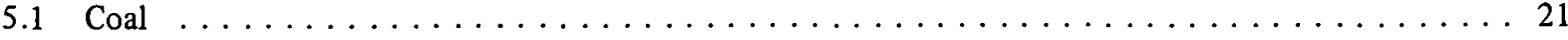

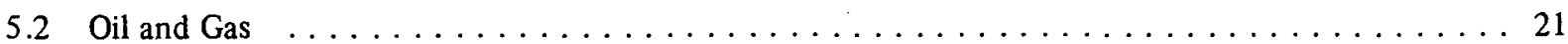

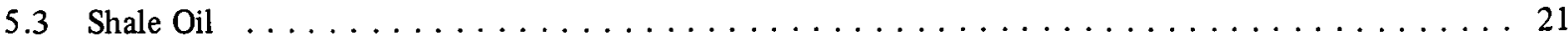

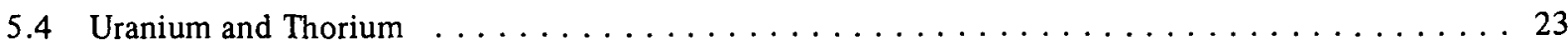




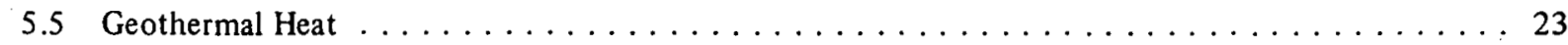

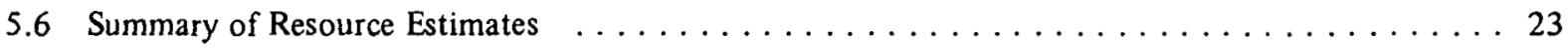

6. LONG-TERM OUTLOOK FOR DOMESTIC FOSSIL FUEL SUPPLY $\ldots \ldots \ldots \ldots \ldots \ldots \ldots \ldots$

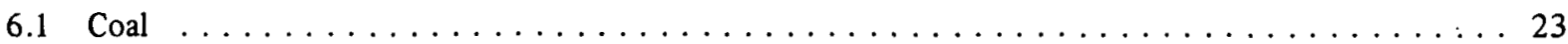

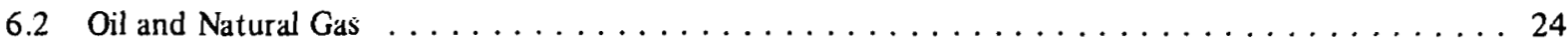




\title{
Consensus Forecast of U.S. Energy Supply and Demand to the Year 2000
}

\author{
J. A. Lane
}

\begin{abstract}
Methods used in forecasting energy supply and demand are described, and recent forecasts are reviewed briefly. Forecasts to the year $\mathbf{2 0 0 0}$ are displayed in tables and graphs and are used to prepare consensus forecasts for each form of fuel and energy supply.

Fuel demand and energy use by consuming sector are tabulated for 1972 and 1975 for the various fuel forms. The distribution of energy consumption by use sector, as projected for the years 1985 and 2000 in the ERDA 48 planning report (Scenario V), are normalized to match the consensus energy supply forecasts. The results are tabulated listing future demand for each fuel and energy form by each major energy-use category.

Recent estimates of U.S. energy resources are also reviewed briefly and are presented in tables for . each fuel and energy form. The outlook for fossil fuel resources to the year 2040 , as developed by the Institute for Energy Analysis at the Oak Ridge Associated Universities, is also presented.
\end{abstract}

\section{DESCRIPTION OF FORECAST METHODS}

\subsection{Methodology of Energy and Electricity Forecasting}

Methods used to project future energy and electricity demand are, for the most part, based on some form of extrapolation of past trends. However, in some cases forecasts have been based on the consensus of experts who presumably also used an extrapolation method. Types of trend extrapolation are discussed in order of complexity in the following paragraphs.

\subsubsection{Intuitive}

In this case an expert looks at past consumption trends and makes an intuitive forecast of future demand.

\subsubsection{Trend Extrapolation (Trend)}

\section{Overall Growth Trends}

Historical data on total energy and electricity consumption are extrapolated using. analy tical or graphical techniques. The must conumunly observed approach involves an exponential function (i.e., a linear relationship on semilogarithmic graph paper). Extrapolations based on declining exponents have also been used. The validity of this approach depends, of course, on the selection of the time period over which trends are to be fitted and on the type of fitting methor used.

\section{Per Capita and Population Growth Trends (Per Capita Trend)}

In this approach, the per capita consumption of energy and/or electricity is projected and combined with population growth forecasts to give total energy and electricity forecasts. In most cases, the population growth is based on forecasts of others (e.g., U.S. Bureau of the Census). A refinement of this approach involves elimination of a segment of the population (e.g., children under 14 years of age).

\subsubsection{Sector Analysis}

A detalled analysis of energy and electricity consumption by each consuming sector (residential, commercial, industrial, transportation, other) is used to forecast sector trends. These forecasts are subsequently combined to give overall projections. Subdivision of sectors in to component parts (e.g., transportation into trains, planes, trucks, private automobiles, etc.) represents a refinement of this forecasting method.

One of the main problems of sector analysis is to ensure that the sectors are appropriately chosen to avoid overlap and ensure comprehensiveness. Sectoral projections, on the other hand, have particular value in providing models of the economy and of energyintensive industries. These models can be critically evaluated and provide data for analysis of individual industries. 


\subsubsection{Energy Source Analysis}

Trends in energy consumption by source of supply (e.g., wood, coal, petroleum, natural gas, hy droelectric power, nuclear) are extrapolated and converted, according to the energy content of each source, into total energy forecasts.

\subsubsection{Regression Analysis (Econometric Model)}

Correlation of energy and electricity growth either on an overall basis or by individual sectors relative to economic variables, such as the gross national product (GNP), consumer spending, investment outlook, labor force, and productivity, provides input data for regression analysis equations or econometric models. This is considered to be the most sophisticated forecasting approach. As in the case of population growth, the related projection is usually carried out by a group other than that doing energy projections.

The most commonly used approach in this category of forecasting relates energy consumption to the GNP forecast. Most such GNP forecasts involve the regression of historical GNP on such factors as population, labor force, and productivity. Each of the individual factors in the GNP regression equation must be extrapolated to arrive at the GNP projection. Thus, although determination of the relationship between energy consumption and GNP seems simple on the surface, in reality many uncertain underlying factors affect GNP and consequently the energy projection.

\subsubsection{Consensus}

Energy and electricity forecasters often use the consensus approach. Included in this approach are methods such as the averaging of forecasts of others, obtaining the consensus of a panel of experts, or conducting polls of experts. In some cases polls are taken in which any one expert is ignorant of the estimates of the others.

\subsubsection{Market Analysis}

Market analyses are usually carried out by sending questionnaires to individual suppliers (fuel companies, equipment manufacturers, utilities, etc.), who project individual future markets. These are combined by those conducting the survey to yield an overall forecast.

\subsection{Methodology of Nuclear Growth Projections}

Nuclear power growth projections usually start with a forecast of future electricity generation (total output of utilities). If the forecast is for total U.S. electricity generation, correction is made for that portion selfgenerated by industry. Utility generation is then converted into future capacity requirements by considering future load factors and reserve requirements. The market for new capacity is computed after allowing for existing capacity, including plants already on order and plants to be retired. Various methods are then used to establish the portion of this capacity that will be nuclear.

\section{REVIEW AND ANALYSIS OF RECENT ENERGY FORECASTS}

Recent forecasts of U.S. energy consumption have been reviewed. The forecasts covered have been divided into two groups, as shown in Tables 1 and 2 . The first group is based on the assumption that historical growth in the demand for energy will continue through the end of the century. This scenario assumes that the nation will not impose policies that might affect our ingrained habit of energy use, but will make a strong effort to develop supplies at a rapid pace to meet rising demand.

The second group of forecasts assumes that a determined conscious national effort to reduce demand for energy through application of energy-saving technologies will be successful and that continued high world oil prices will keep domestic energy prices high, resulting in lower demand. Some forecasters in this group even go so far as to project achievement of a zero energy growth rate by the year 2000 .

Although many of the forecasters present intermediate-growth scenarios that fall between the extremes of the historical growth rate basis and the conservation basis figures, these are not shown in Tables 1 and 2. Figure 1 shows a plot of the average of each group of forecasts.

According to recent trends, the lower conservationoriented forecasts appear to represent the most likely future total energy requirement. A suitable range of values in quads $\left(10^{15} \mathrm{Btu}\right)$ would be as follows:

$\begin{array}{lccrr} & 1975 & 1980 & 1985 & 2000 \\ \text { Low } & 73 & 85 & 95 & 120 \\ \text { High } & 79 & 95 & 110 & 150\end{array}$

\subsection{Associated Universities, Inc., Reference Energy Systems and Resource Data for Use in the Assessment of Energy Technologles, PB-221 422 (also AET-8), May 1972}

A projection of future energy demand to the year 2020 is made on the basis of each end use of energy, 
Table 1. Historical growth forecasts of U.S. total energy consumption (preembargo)

\begin{tabular}{|c|c|c|c|c|c|c|c|c|c|}
\hline \multirow{2}{*}{ Forecaster } & \multirow{2}{*}{$\begin{array}{l}\text { Date of } \\
\text { forecast }\end{array}$} & \multicolumn{5}{|c|}{ Energy consumption (quads) ${ }^{a}$} & \multicolumn{3}{|c|}{ Growth rate (percent per year) } \\
\hline & & 1975 & 1980 & 1985 & 2000 & 2020 & $1975-1985$ & $1986-2000$ & $2001-2020$ \\
\hline Associated Universities, Inc. & May 1972 & 80 & 98 & 118 & 179 & 302 & 4.0 & 2.8 & 2.7 \\
\hline Intertechnology Corporation & Nov. 1972 & 75 & 87 & 99 & 150 & 260 & 2.8 & 2.8 & 2.8 \\
\hline National Petroleum Council & Dec. 1972 & 83 & 108 & 125 & 200 & & 4.2 & 3.2 & \\
\hline $\begin{array}{l}\text { Department of the Interior } \\
\text { (Dupree-West) }\end{array}$ & Dec. 1972 & 80 & 96 & 117 & 192 & & 3.9 & & \\
\hline Stanford Research Institute & May 1973 & 79 & 101 & 131 & & & 5.2 & & \\
\hline Westinghouse (P. N. Ross) & June 1973 & & & & 206 & & & & \\
\hline $\begin{array}{l}\text { Joint Committee on Atomic } \\
\text { Energy Staff }\end{array}$ & Aug. 1973 & 81 & 102 & 125 & 212 & & 4.4 & 3.6 & , \\
\hline NASA/ASEE TERRASTAR & Sept. 1973 & 80 & 97 & 119 & 206 & 377 & 4.1 & 3.7 & 3.1 \\
\hline $\begin{array}{l}\text { U.S. Atomic Energy Commission } \\
\text { (D. L. Ray) }\end{array}$ & Dec. 1973 & 81 & 98. & 121 & 197 & 280 & 4.1 & 3.3 & 1.8 \\
\hline Ford Foundation & Early 1974 & 81 & 95 & 115 & 185 & & 3.6 & 3.2 & \\
\hline $\begin{array}{l}\text { U.S. Atomic Energy Commission } \\
\text { (Office of Planning and Analysis) }\end{array}$ & Feb. 1974 & 81 & 98 & 117 & 195 & & 3.8 & 3.5 & \\
\hline L. T. Blank and R. K. Riley & Mar. 1974 & 88 & 198 & 127 & 187 & 288 & 3.7 & 2.5 & 2.2 \\
\hline National Petroleum Council & Mar. 1974 & 82 & 98 & 114 & & & 3.4 & & \\
\hline National Academy of Engineering & May 1974 & 84 & 101 & 123 & & & 3.9 & & \\
\hline Average & & 81 & 99 & 120 & 192 & 301 & 4.0 & 3.2 & 2.3 \\
\hline
\end{tabular}

${ }^{a}$ One quad $=10^{15}$ Btu.

Table 2. Conservation-oriented forecasts of U.S. total energy consumption (postembargo)

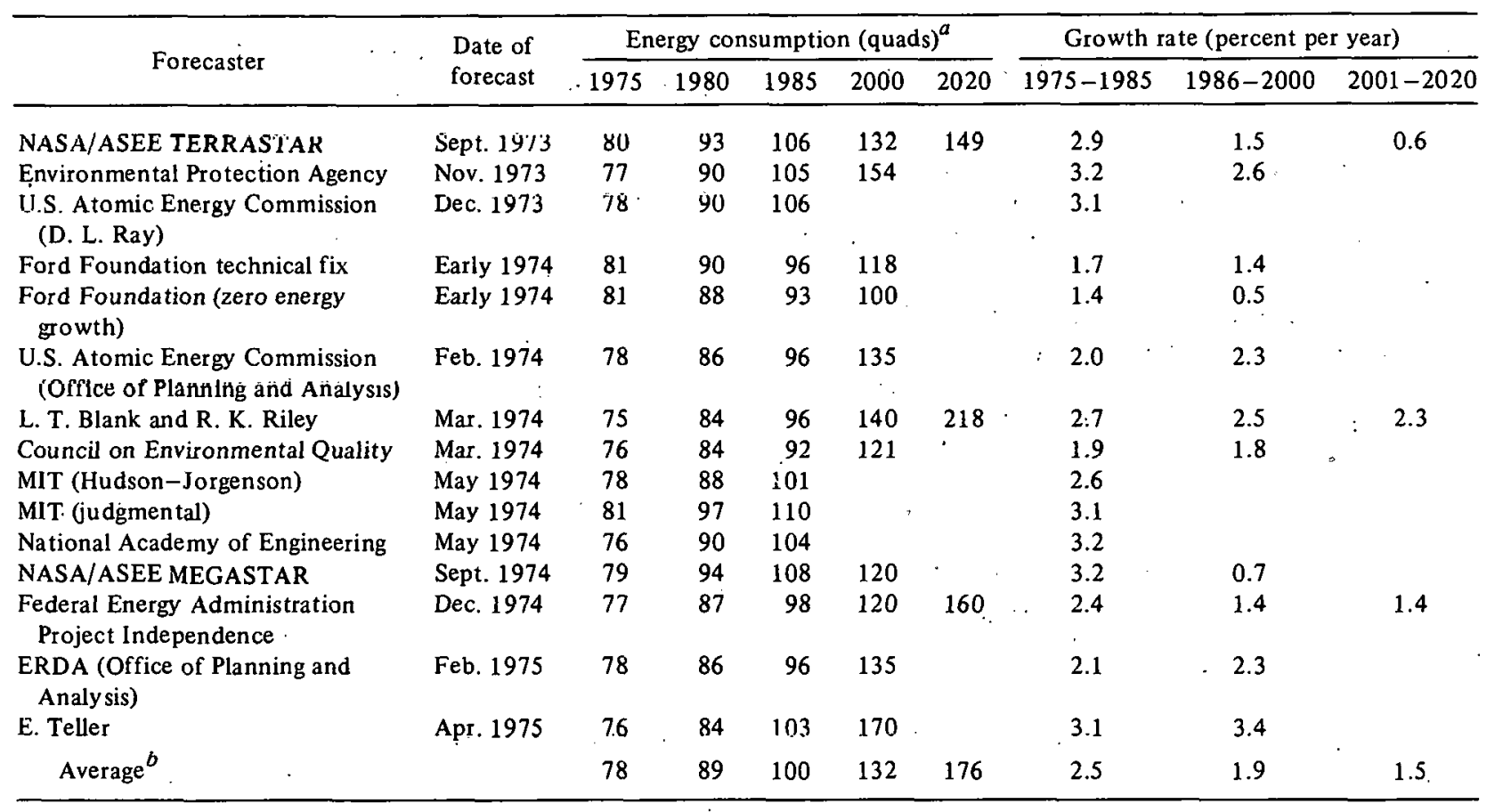

${ }^{a}$ One quad $=10^{15} \mathrm{Btu}$.

${ }^{b}$ Average excludes Ford Foundation zero energy growth forecast. 


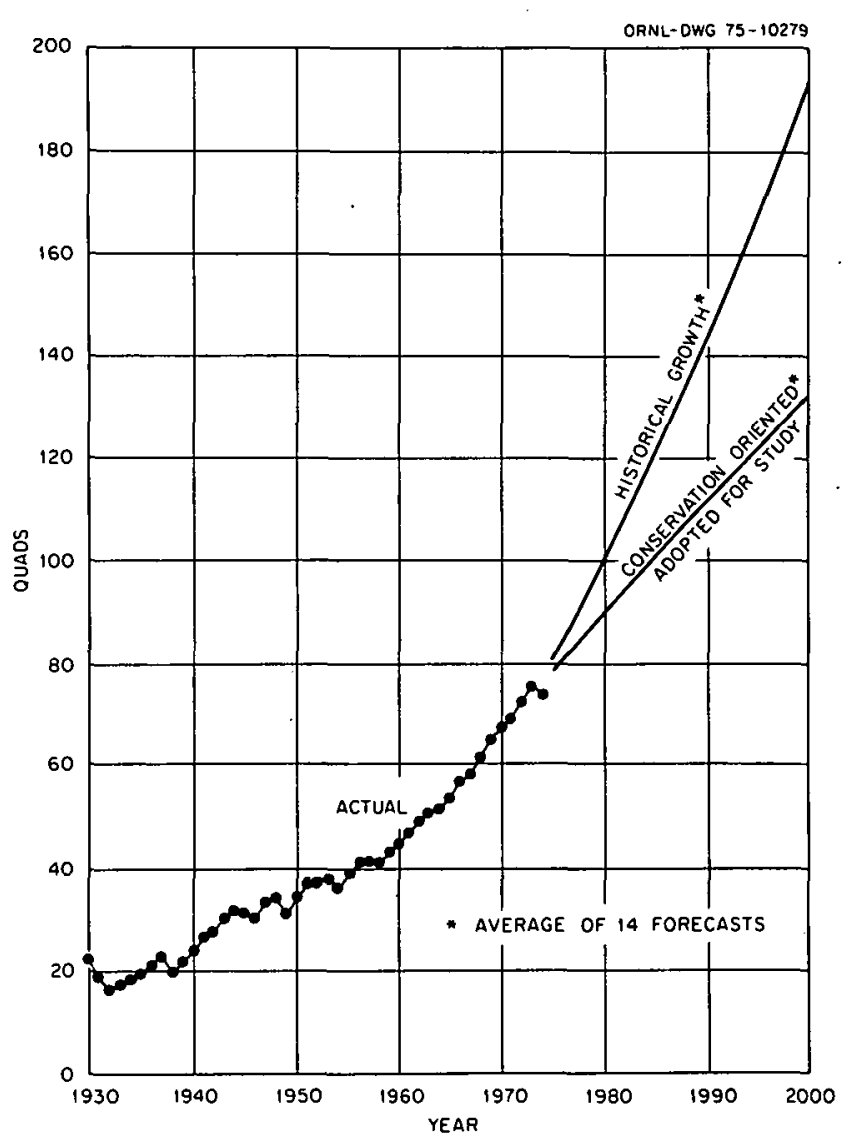

Fig. 1. United States total energy consumption.

hroken down into 27 individual consuming sectors. Historical trends, adjusted for possible saturation effects, were used to establish a growth trend for each sector. Reference energy systems to define sources and end uses of energy for the years 1969, 1977, 1985, 2000 , and 2020 were then established. Total resource consumption was estimated to reach 177 quads by the year 2000 and 299 quads by 2020 . The possible effect of high energy costs on energy demand was not taken into consideration.

\subsection{Intertechnology Corporation, The U.S. Energy Problem, for NSF-RANN,} November 1972

This report surveyed 56 separate projections and used curve-fitting techniques to develop a total-energy-time equation:

$$
\mathrm{E}_{\mathrm{T}}=65.57 \times 10^{15} \times 1.028^{(\text {year }-1970)} \mathrm{Btu} / \text { year } .
$$

This equation continues the exponential growth of total energy consumption of the past 30 or more years. The forecasts surveyed in this study were made in the early to mid-1960s.

\subsection{National Petroleum Council, Guide to NPC Report on U.S. Energy Outloak, December 1972}

In July 1971, the National Petroleum Council issued an initial appraisal of the U.S. energy outlook based on optimistic assumptions of what could occur without major changes in the political and economic climate. The projected total energy demand of 125 quads by 1985 (up from 68 quads in 1970) was still considered a valid intermediate case as of December 1972, the date of publication of the report. This projection was based on an economic growth rate of $4.2 \%$ per. year (real GNP), no future changes in real energy costs, and a population growth of $1.1 \%$ per year. An accompanying longer range projection indicated a consumption of 200 quads by the year 2000 .

\subsection{W. G. Dupree and J. A. West, United States}

Energy Through the Year 2000, Department of the Interior, U.S. Government Printing Office, December 1972

This report was written prior to the current high oil prices and represents a forecast of future energy demand based on conditions existing in 1972. It gives a wealth of historical data and a good analysis of energy consumption by sources of energy and by consuming sectors. Thus it is an excellent background paper for any study of tuture energy supply. The accual projected consumption of total energy in quads is 80.3 in 1975 , 96 in 1980, 116.8 in 1981 , and 191.9 in 2000.

\subsection{S. Field, Stanford Research Institute, "The U.S. Energy Puzzle," paper presented at 38th midyear meeting of Division of Refining, Philadelphia, May 1973}

A sectoral analysis of the demand for energy led to a forecast total energy demand of 131 quads by 1985 . Limited domestic supplies, however, might reduce this figure to 119 quads.

\subsection{P. N. Ross, Westinghouse Electric Corporation, "The Nuclear Electric Economy," paper presented at the Conference on the Hydrogen Economy, Miami, Fla., March 1974}

"The Nuclear Electric Economy" scenario was prepared in 1973 and modified after the oil embargo. It is based on the premise that any realistic approach to 
solving the energy crisis should be based on reducing U.S. dependence on oil and gas. It therefore proposes that a shift be made to a more abundant fuel base. In particular, the scenario suggests an economy that is strongly dependent on the electricity generated by nuclear fission and coal. In this scenario the production of electricity by the year 2000 is up $50 \%$, while the use of oil and gas is down by a factor of 3 . The use of coal is up over $70 \%$, and total energy end-use consumption is down more than $30 \%$. The paper suggests that this trend in consumption would be possible if the end uses of electricity could be made more efficient. Technological changes necessary for such a trend include the use of heat pumps for space-heating applications and the use of electric-powered vehicles in the transportation scetor. Despite the greater end-use efficiencies postulated, the nuclear electric economy approach requires essentially the same total energy input as the "business as usual" case (200 quads in the year 2000 compared to 206 quads). Required imports of oil and gas, however, would be zero by the year 2000 .

\subsection{Joint Committee on Atomic Energy, Understanding the National Energy Dilemma, Joint Committee Print, August 1973}

Recent appraisals of the nation's energy demand through the year 2000 were evaluated and used as a basis for "option exercise" projections by the Joint Committee staff. The staff believed that one particular exercise, option exercise $7 \cdot \Lambda$, was one of the more balanced of the several exercises examined. This option calls for a depressed demand of 82 million bbl/day oil-equivalent (174 quads) by the year 2000. This amount is $25 \%$ below what would result if the United States were to continue its current growth rates in energy use. Even with this figure, however, imports and/or shortages were forecast by the staff to amount to 13 million bbl/day oil-equivalent.

\subsection{NASA/ASEE-Auburn University, Terrestrial Applications of Solar Technology and Research (TERRASTAR), September 1973}

Ten forecasts of energy consumption in the United States are reviewed and an upper and a lower limit to consumption defined. The prohable impasts of fol. lowing either of these Iwo energy-growth scenarios are discussed. The conclusion is that a third scenario, involving a national energy policy aimed at rational conservation-oriented energy use, would be preferable. The annual growth in energy consumption with this scenario would decrease from a current rate of about $3.6 \%$ to about $1 \%$ by the year 2000 and $0.5 \%$ by 2020 .
The corresponding forecast of energy consumption is 132.2 quads by the year 2000 and 148.8 quads by 2020.

\subsection{Environmental Protection Agency, Alternative Futures and Environmental Quality, Office of Research and Development, November 1973}

The scenario presented by the Environmental Protection Agency provides a good explanation of the interactions between population, GNP, pollution, and energy consumption. The four possible futures described are high population and high economic growth, low population and low economic growth, and two intermediate alternatives. The low-population and lowgrowth case projects an energy consumption of 158 quads in the year 2000 .

\subsection{L. Ray, The Nation's Energy Future, WASH-1 281, U.S. Atomic Energy Commission, December 1973}

This report was prepared in response to President Nixon's directive in his June 29, 1973, energy message. Its purpose and scope are to recommend a national energy research and development program needed to regain and maintain energy self-sufficiency. The report was developed under the guidance of the Energy Policy Office in conjunction with various government departments and agencies having energy responsibilities. A five-year $R \& D$ program involving five tasks was suggested. as a means of achieving the desired objectives. These tasks are: (1) conserve energy and energy resources, (2) increase domestic production of oil and gas; (3) substitute coal for oil and gas, (4) validate the nuclear option, and (5) exploit renewable resources. In order for the United States to achieve self-sufficiency by 1985 , the growth in energy demand would have to be held to 90 quads by 1980 and 106 quads by 1985 .

\subsection{Ford Foundation, Exploring Energy Choices, preliminary report of Energy Policy Project of the Ford Foundation, early 1974}

This report describes the following three scenarios (alternative energy futures), which are based on different assumptions regarding possible growth patterns our society might adopt.

\begin{tabular}{lcccccc} 
& \multicolumn{6}{c}{ Energy consumption (quads) } \\
\cline { 2 - 7 } & 1975 & 1980 & 1985 & 1990 & 1995 & 2000 \\
Historical growth & 80 & 95 & 115 & 136 & 160 & 185 \\
Technical fix & 80 & 87 & 96 & 104 & 110 & 118 \\
Zero energy growth & 80 & 87 & 93 & 95 & 98 & 100
\end{tabular}


The historical growth scenario assumes that the nation will not impose policies that will influence traditional habits of energy use. The technical fix scenario reflects a determined conscious national effort to reduce energy demand through conservation while still maintaining a quality of life comparable to that of historical growth. The zero energy growth scenario represents a real break with our accustomed way of living; however, it does not preclude economic growth. Also it allows the less privileged to catch up on the comforts of life.

\subsection{Office of Planning and Analysis, Nuclear Power Growth 1974-2000, WASH-1139(74), U.S. Atomic Energy Commission, February 1974}

Four scenarios of future energy demand and associated nuclear generating capacity are evaluated, ranging from a minimum forecast of 135.3 quads (nuclear capacity of 47.8 quads) to a high of 199.6 quads (nuclear capacity of 78.5 quads) by the year 2000 . The minimum forecast assumes a slowdown in the rate of economic growth due to an increase in the efficiency of energy use and a reduction of demand. The high forecast, on the other hand, assumes a continuation of the past relationship between energy consumption and GNP together with an increase in the importance of electricity as a secondary energy source. The cases discussed are not intended to specify precise future situations, but rather to provide a reasonable range of estimates of probable demands for energy and the contributions of nuclear energy to the supply.

\subsection{T. Blank and R. K. Riley, "Future U.S. Demand Patterns and Use of Hydrogen," paper presented at the Conference on the Hydrogen Economy, Miami, Fla., March 1974}

The demand forecasts in this paper do not follow any of the conventional methods but use a method of saturation forecasting applicable to most areas of energy use. The saturation concept reflects the inability of an individual or household to use more than a certain amount of energy because of time and spatial constraints. The results of this approach, therefore, provide an upper limit to the growth in energy demand. Tis upper limit amounts to 187 quads by the year 2000 and 288 quads by 2020 . The authors also make a conservation demand forecast by taking into consideration environmental factors, scarcity of energy sources, and costs. This latter approach indicates a demand for 140 quads by the year 2000 . Hydrogen convertibility for each use area is also estimated, based on results of a 1973 NASA/ASEE Summer Design Institute.

\subsection{Council on Environmental Quality, A National Energy Conservation Program - The Half and Half Plan, March 1974}

The scenario presented by the Council on Environmental Quality is a response to the energy crisis of 1973-1974 and is based on the assumption that unrestrained growth of energy consumption is impossible and environmentally undesirable. The council proposes that the projected growth in energy consumption be cut by half through conservation and that the remaining half be met through expansion of domestic energy sources. The scenario is essentially a future based on an electric economy, with petroleum used almost exclusively for transportation. The postulated energy demand reaches 121 quads by the year 2000 .

\subsection{National Petroleum Council, Energy Conservation in the United States - Short Term Potential, 1974-1978, March 1974}

The National Petroleum Council's (NPC) intermediate demand projection in their December 1972 report U.S. Energy Outlook was adopted as a starting point for a Consumption/Energy Demand Task Group study; however, the projection was reduced to allow for a $1 \%$ per year population growth rate instead of a $1.1 \%$ rate and an energy price increase in constant dollars of $100 \%$ between 1970 and 1985 . The resulting projection indicates an energy consumption growth of $3.8 \%$ per year to $1977,3.5 \%$ per year frum 1978 to 1980 , and $3.3 \%$ per year from 1981 to 1985 . Ihese growth rates lead to a projected total energy consumption of 114.4 quads by 1985 .

\subsection{A. Adelman et al., "Energy Self Sufficiency, An Economic Viewpoint," Technol. Rev. 76(6), 22 (May 1974)}

This Massachusetts Institute of Technology study seeks to evaluate the state of the economy under energy self-sufficiency. On the assumption that the United States meets all its energy demands from internal sources by 1980 , forecasts are made of the energy prices at which supply and demand will be in equilibrium. The results indicate that prices of $\$ 10$ to $\$ 12$ per barrel (oil-equivalent) will be necessary to reach the stated goal. Econometric supply and demand models taking price elasticity into consideration are compared with judgmental models that generally ignore price response. Because each approach has its own weakness, 
judgmental and econometric methods should be used to complement one another. On this basis, one might expect the energy supply and demand to balance out at about 90 quads by 1980 with the above energy prices.

\subsection{R. C. Seamans, U.S. Energy Prospects: An Engineering Viewpont, National Academy of Engineering, May 1974}

This report summarizes the findings of a task force appointed to provide an informal, measured, and prompt assessment of the technological range of actions that would have to be taken if the United States chose to become as independent as possible of foreign sources of energy by 1985. The results indicate that on the basis of historical trends, the United States would consume the equivalent of 58 million bbl/day of oil by $1985\left(123 \times 10^{15} \mathrm{Btu}\right)$. However, if major incentives are undertaken to conserve the use of energy, this demand could possibly be reduced to about 51 million bbl/day of oil. In 1972, it was projected that domestic sources could supply about 40 million bbl/day of oil-equivalent by 1985 . This 1974 study finds that if appropriate and timely actions are taken, domestic production could be increased to about 49 million bbl/day of oil by 1985. In the meantime, however, oil imports will probably rise from a current level of about 6.6 to 8 or 9 million bbl/day of oil by 1977 or 1978 . The task force considered the possibility, as well as desirability, of ceasing oil importation altogether by 1985 to be questionable.

\subsection{NASA/ASEE-Auburn University, MEGASTAR \\ (The Meaning of Energy Growth: An Assessment of Systems, Technologies and Requirements); Report NASA/CR-120338, September 1974}

This study reviews recent energy consumption forecasts and chooses two as particular futures to evaluate - the nuclear electric economy described by Westing. house in June 1973 and the Ford Foundation technical fix base case published early in 1974. The former is considered to be representative of historical energy growth forecast, while the latter is representative of a future based on a national effort to reduce demand through the application of energy-saving technologies. The study group analyzed one additional scenario in detail, which, though similar to the Ford technical fix base case, had the additional assumption that a zero energy growth rate might be achieved by the year 2000 . Energy consumption according to this latter scenario was projected to reach 108 quads by 1985,116 quads by 1990 , and 120 quads by 2000 .

\subsection{Federal Energy Administration, Project Independence Report, November 1974}

This study contrasts the U.S. energy supply and demand situation based on world oil prices of $\$ 7$ per barrel and $\$ 11$ per barrel. At the lower price, total energy demand would grow at $3.2 \%$ per year through 1985 and reach a level of 109.6 quads. Petroleum consumption would reach 23 million bbl/day. At $\$ 11$ per barrel world oil prices, total energy demand would be reduced to a growth rate of $2.75 \%$ per year, resulting in a 1985 energy demand of 103 quads in the base case and 96.3 quads with energy conservation. Petroleum consumption in this latter case would be reduced to 18 million bbl/day. The domestic supply of energy would also be influenced by world oil prices. At $\$ 7$ per barrel, domestic supply would reach 84.2 quads in the base case and 88.5 quads with an ambitious program to accelerate supply. At $\$ 11$ world oil prices, economic forces would push domestic energy supplies to 96.3 quads, resulting in a no-oil-import situation.

\subsection{Office of Planning and Analysis, Total Energy, Electric Energy and Nuclear Power Projections, \\ United States, Energy Research and Development Administration, February 1975}

The Office of the Assistant Administrator for Planning and Analysis has completed a new examination and prepared new projections of energy, electric power, and nuclear power for the United States through the year 2000 . These estimates update the forecasts published in Nuclear Power Growth, 1974-2000 [WASH1139(74)], prepared in February 1974.

The total energy and electric power projections are derived through the use of econometric analyses and energy network flows developed by Brookhaven National Laboratory. The econometric work relates population, employment, and productivity factors to project GNP. Total energy resource consumption and energy inputs to the electrical sector are related to GNP growth to provide aggregate values for guiding the more detailed fuel substitution possibilities.

The three total energy cases developed are the same energy projections used in cases $A, D$, and $B$ in the previous forecast. For the year 2000 the forecasts are as follows: high, 195 quads; moderate, 174 quads; and low, 135 quads. 
2.21 E. Teller, Energy - A Plan for Action, report to the Energy Panel of the Commission on

Critical Choices for Americans, April 1975

In this paper Teller presents, not a forecast of future energy demand, but a target for what demand should be. A proposed plan for achieving a target figure of 103 quads by 1985 and 170 quads by the year 2000 is presented. The elements of the plan are

1. economic and effective use of energy,

2. increased domestic oil and gas production,

3. much greater use of coal,

4. public acceptance of and greater use of nuclear energy.

\section{ENERGY CONSUMPTION BY SOURCE}

\subsection{Method of Approach}

Recent studies ${ }^{1-24}$ of the U.S. future energy supply and demand problem were critically reviewed as a basis for establishing a "most likely" energy supply and demand scenario to the year 2000 . Forecasts of total energy consumption were used as the starting point. These forecasts were grouped into two classes, representing historical-growth (preembargo) and conservation-oriented (postembargo-high oil price) conditions respectively. The averages for selected years of 15 conservation-oriented forecasts were judged to be representative of the most likely future energy demand.

The next step involved the development of an electricity demand forecast. Because one might expect that the same conservation-oriented forces that inhibit total energy demand would likewise influence electricity demand, electricity was correlated as a function of percentage of total energy demand for both the historical-growth and conservation-oriented forecasts.

Use of this correlation revealed that all forecasts were in fairly close agreement and that the four forecasts given in the 1975 version of WASH-1 $139^{22}$ generally covered the spread of the forecasts. The averages of these four cases were adopted for this study.

Applying these average percentages to the previously derived total energy projections gave the electricity

1. Associated Universities, Inc., Reference Energy Systems and Resource Data for Use in the Assessment of Energy Technologies, PB-221 422 (also AET-8), May 1972.

2. Intertechnology Corporation, The U.S. Energy Problem, NSF/RANN-71-019, November 1971.
3. National Petroleum Council, Guide to NPC Report on U.S. Energy Outlook, December 1972.

4. W. G. Dupree and J. A. West, United States Energy Through the Year 2000, Department of the Interior, U.S. Government Printing Office, December 1972.

5. S. Field (Stanford Research Institute), "The U.S. Energy Puzzle," Proceedings of the Division of Refining, 1973, Philadelphia, Pennsylvania, American Petroleum Institute, Washington, D.C., May 1973.

6. P. N. Ross, Westinghouse Electric Corporation, "The Nuclear Electric Economy," paper presented at the Conference on the Hydrogen Economy, Miami, Fla., March 1974.

7. Joint Committee on Atomic Energy, Understanding the National Energy Dilemma, Joint Committee Print, August 1973.

8. NASA/ASEE-Auburn University, Terrestrial Applications of Solar Technology and Research (TERRASTAR), NASA/CR129012 , September 1973.

9. Environmental Protection Agency, Alternative Futures and Environmental Quality, Office of Research and Development, November 1973.

10. D. L. Ray, The Nation's Energy Future, U.S. Atomic Energy Commission, WASH-1281, December 1973.

11. Office of Planning and Analysis, Nuclear Power Growth 1974-2000, WASH-1139(74), U.S. Atomic Energy Commission, February 1974.

12. L. T. Blank and R. K. Riley, "Future U.S. Demand Patterns and Use of Hydrogen," paper presented at the Conference on the Hydrogen Economy, Miami, Fla., March 1974.

13. Council on Environmental Quality, A National Energy Conservation Program - The Half and Half Plan, March 1974.

14. National Petroleum Council, Energy Conservation in the Unitod States - Short Term Potential. 1974-1978, March 1974.

15. M. A. Adelman et al., "Energy Self Sufficiency, An Economic Viewpoint," Technol. Rev. 76(6), 22 (May 1974).

16. R. C. Seamans, U.S. Energy Prosperts: An Engineering Viewpoint, National Academy of Engineering, May 1974.

17. NASA/ASEE - Auburn University, MEGASTAR (The Meaning of Energy Growth: An Assessment of Systems, Technologies and Requirements), NASA/CR-120338, September 1974 .

18. Federal Energy Administration, Project Independence Report, November 1974.

19. Ford Foundation, A Time to Choose - America's Energy Future, final report of the Energy Policy Project, Ballinger Publishing Co., Cambridge, Mass., 1974.

20. J. W. Duane and M. A. Karnitz, "Domestic Gas Resources and Future Production Rates," Power Eng. 79(1), 36-39 (January 1975).

21. C. E. Whittle and D. B. Reister, The IEA Energy Simulation Model: A Framework for Long-Range U.S. Energy Analysis, Institute for Energy Analysis, January 1975.

22. Office of Planning and Analysis, Total Energy, Electric Energy and Nuclear Power Projections, United States, Energy Research and Development Administration, February 1975.

23. J. D. Moody and R. E. Geiger, "Petroleum Resources How Much Oil and Where?" Technoi. Rev. 77(5), 38-45 (March-April 1975).

24. E. Teller, Energy - A Plan for Action, report to the Energy Panel of the Commission on Critical Choices for . Americans, April 1975. 
demand forecast. The corresponding electrical generating capacities were calculated from the demand data using ERDA's projected system heat rates and capacity factors. ${ }^{22}$

A nuclear generation capacity forecast was obtained by averaging the ERDA low and moderate/low forecasts. $^{22}$ The corresponding nuclear power generation was then calculated using ERDA's forecast heat rates for nuclear plants and assuming that nuclear plant capacity factors would level off at $70 \%$ (same as the ERDA high case). This assumption should be valid, since the projected installed nuclear capacity reaches only $50 \%$ of the total installed capacity by the year 2000.

Using the same approach as for electricity projections, a coal consumption forecast was obtained by plotting coal forecasts as a percentage of total energy for both the preembargo and postembargo forecasts. Here the agreement was not good between the two types of forecasts; therefore, only the postembargo forecasts were used to obtain an estimate of future coal consumption.

Forecasts of domestic natural gas and petroleum production were plotted, and a judgment (best guess) forecast was made for each of these sources of supply. In the case of natural gas supply, the judgment forecast was the same as that of Duane and Karnitz of Consumers Power Company ${ }^{20}$ based on a total resource of $1500 \times 10^{12} \mathrm{ft}^{3}$.

The projected contribution of hydroelectric power was based on an average of available forecasts. This average is close to the Office of Planning and Analysis's moderate projection and represents a continuation of the recent growth of hydroelectric power.

The contribution of geothermal and solar energy was estimated, based on an average of various forecasts for the years 1985 and 2000.

Wood and waste materials consumption was assumed by the year 2000 to reach a level equal to wood in the early 1950 s.

The requirements for imported oil were obtained as an end result by subtracting the combined contribution of domestic energy supplies from the forecast total energy demand.

\subsection{Total Energy Consumption}

Forecasts of total energy consumption are given in Tables 1 and 2. The historical-growth forecasts for 1985 are generally in the range of 115 to 130 quads, which corresponds to an annual growth rate of about $4 \%$. With this scenario, energy consumption would reach 180 to 210 quads by the year 2000 and 300 quads by 2020 .
The conservation-oriented forecasts shown in Table 2, on the other hand, project a demand of only 90 to 110 quads by 1985 and about 120 to 140 quads by the year 2000. Average annual growth rates with these forecasts would be $2.5 \%$ up to 1985 and $1.9 \%$ from 1986 to 2000. The averages of the two types of forecasts are plotted in Fig. 1 along with historical data on total energy consumption. In view of the current oil price situation, the conservation-oriented forecast appears to represent the most likely trend of future energy demand.

\subsection{Coal Consumption Forecasts}

Forecasts of U.S. coal consumption (which, in some cases, are also production figures) in terms of energy content are listed in Table 3 and plotted in Fig. 2. Because of the wide spread of data it was not possible to obtain a consensus type of correlation. Figure 3 shows a second plot of selected coal consumption forecasts in terms of percentage of total energy used. Forecasts that did not take into consideration an increasing dependence on coal for the production of electricity and synthetic liquid and gaseous fuels were not included in this plot. The correlation indicated by dots in Fig. 3 was adopted for this study. These percentages were applied to the total energy forecast to obtain the coal consumption forecast shown in Table 4. The average heat content data used in this table were obtained from a straight-line extrapolation of the 25-year trend in the United States from 1950 to 1974.

\subsection{Domestic Natural Gas Production}

Forecasts of domestic natural gas production are plotted in Fig. 4. With a few exceptions, the forecasts show that natural gas production will peak in the late 1980 s and reach a maximum production level in the range of 20 to 30 quads/year. The height of the peak will depend on the magnitude of the total recoverable resources. Assuming these recoverable resources to be of the order of $1500 \times 10^{12} \mathrm{ft}^{3}$ or 1545 quads (estimates range between 1200 and $1800 \times 10^{12} \mathrm{ft}^{3}$ ), the forecast by Duane and Karnitz of Consumers Power Company appears to represent the maximum production that may be expected under even the best of conditions. This forecast indicates a peak production of 26 quads in 1986 and a reduction to 20 quads by the year 2000 . A recent U.S. Geological Survey publication on U.S. oil and gas reserves ${ }^{25}$ indicates that measured,

25. B. M. Miller, H. L. Thomsen et al., Geological Estimates of Undiscovered Recoverable Oil and Gas Resources in the United States, U.S. Geological Survey Circular 725, (1975). 
Table 3. Forecasts of coal consumption

\begin{tabular}{|c|c|c|c|c|c|}
\hline \multirow{2}{*}{$\begin{array}{l}\text { Key to } \\
\text { Fig. } 2\end{array}$} & \multirow[b]{2}{*}{ Forecaster } & \multicolumn{2}{|c|}{1985} & \multicolumn{2}{|c|}{2000} \\
\hline & & Quads & $\begin{array}{l}\text { Percent of } \\
\text { total energy }\end{array}$ & Quads & $\begin{array}{l}\text { Percent of } \\
\text { total energy }\end{array}$ \\
\hline 1 & Associated Universities, Inc. & 21.6 & 18.3 & 36.5 & 20.3 \\
\hline 2 & MIT (Hudson-Jorgenson) & 16.5 & & 26.9 & \\
\hline 3 & Westinghouse (Ross) & 34.0 & 30.9 & 66.0 & 31.9 \\
\hline 4 & NASA/ASEE TERRASTAR & 21.2 & 19.9 & 40.7 & 30.8 \\
\hline 5 & U.S. Atomic Energy Commission (D. L. Ray) & 29.4 & 27.8 & & \\
\hline 6 & Ford Foundation technical fix ${ }^{a}$ & 15.0 & 16.3 & 25.5 & 20.7 \\
\hline 6 & Ford Foundation historical growth ${ }^{a}$ & 24.3 & 21.1 & 42.0 & 22.4 \\
\hline 7 & $\begin{array}{l}\text { U.S. Atomic Energy Commission/Office of Planning } \\
\text { and Analysis } \\
\text { WASH-1139(74) - case A } \\
\text { WASH-1139(74) - case B } \\
\text { WASH-1139(74) - case C } \\
\text { WASH-1 139(74) - case D }\end{array}$ & $\begin{array}{l}19.3 \\
22.3 \\
26.0 \\
20.0\end{array}$ & $\begin{array}{l}20.1 \\
19.1 \\
21.7 \\
19.1\end{array}$ & $\begin{array}{l}23.6 \\
28.9 \\
29.1 \\
26.1\end{array}$ & $\begin{array}{l}17.4 \\
14.8 \\
14.6 \\
15.0\end{array}$ \\
\hline 8 & Department of the Interior (Dupree-West) & 21.5 & 18.4 & 31.4 & 16.3 \\
\hline 9 & National Academy of Engineering & 25.3 & 25.6 & & \\
\hline 10 & NASA/ASEE MEGASTAR & 21.2 & 18.3 & 24.8 & 20.7 \\
\hline 11 & $\begin{array}{l}\text { Federal Energy Administration } \\
\text { Project Independence (business as usual) } \\
\text { Project Independence Task Force (business as usual) } \\
\text { Project Independence Task Force (accelerated supply) }\end{array}$ & $\begin{array}{l}22.9 \\
25.0 \\
46.9\end{array}$ & $\begin{array}{l}22.2 \\
24.3 \\
43.0\end{array}$ & $\begin{array}{l}29.6(1990) \\
63.8(1990)\end{array}$ & \\
\hline 12 & E. Teller & 33.0 & 28.0 & & \\
\hline 13 & ERDA (synopsis from Coal Scenario II) & 23.3 & 21.7 & 49.8 & 30.1 \\
\hline
\end{tabular}

${ }^{a}$ Average of alternative scenarios.

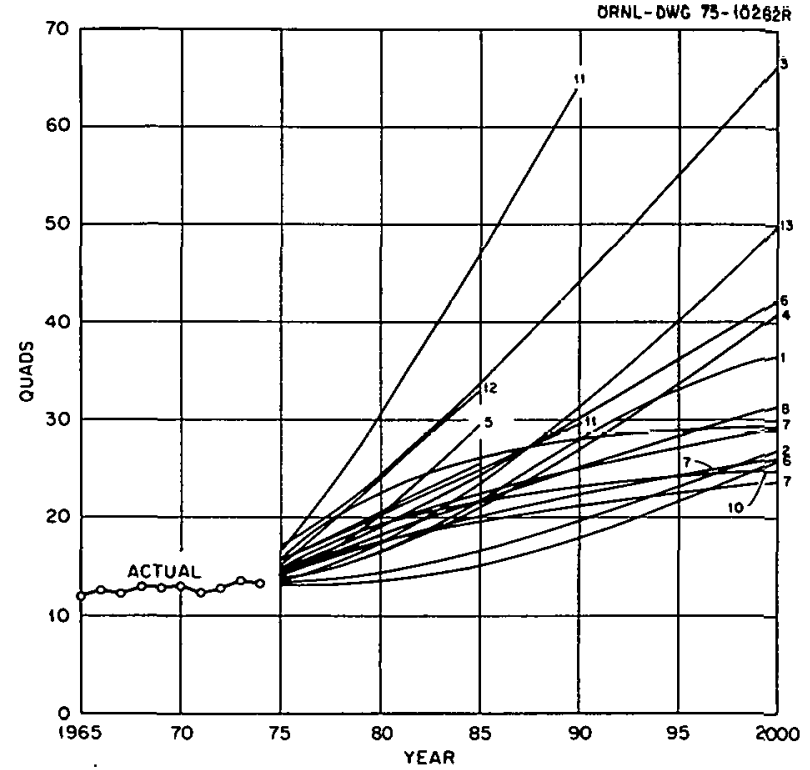

Fig. 2. Coal consumption and production forecasts. Note: See Table 3 for reference numbers. inferred, and undiscovered recoverable reserves with a 95\% probability of discovery amount to 1242 quads. This publication states that there is only a $5 \%$ probability of discovering as much as 1575 quads $^{25}$ (see Sect. 5 below). Table 5 gives the selected forecast of natural gas production.

\subsection{Domestic Oil Production}

Forecasts of domestic oil production (including natural gas liquids and shale oil) are plotted in Fig. 5 . As in the case of natural gas production, most forecasts show that domestic oil production from all sources might peak in the late 1980 s, reaching a level in the range of 22 to 30 quads/year ( 10 to 14 million bbl/day). According to Geiger and Moody ${ }^{23}$ the total domestic recoverable resources of crude oil (including undiscovered potential sources) may amount to $230 \times$ $10^{9} \mathrm{bbl}$, of which $100 \times 10^{9} \mathrm{bbl}$ were produced up to 1974. The curve shown in Fig. 5, adopted for the study, would utilize $85 \%$ of this potential resource by the year 
Table 4. Selected forecast of U.S. coal consumption

\begin{tabular}{ccccc}
\hline Year & $\begin{array}{c}\text { Percent of } \\
\text { total energy }\end{array}$ & Quads & $\begin{array}{c}\text { Average heat content } \\
\text { (millions of Btu per ton) }\end{array}$ & $\begin{array}{c}\text { Millions of } \\
\text { tons per year }\end{array}$ \\
\hline 1975 & 18.7 & 14.1 & 23.8 & 590 \\
1980 & 21.2 & 18.7 & 23.4 & 800 \\
1985 & 23.3 & 23.3 & 23.0 & 1010 \\
1990 & 25.7 & 28.3 & 22.6 & 1250 \\
1995 & 27.9 & 33.8 & 22.2 & 1520 \\
2000 & 30.0 & 39.9 & 21.7 & 1825 \\
\hline
\end{tabular}

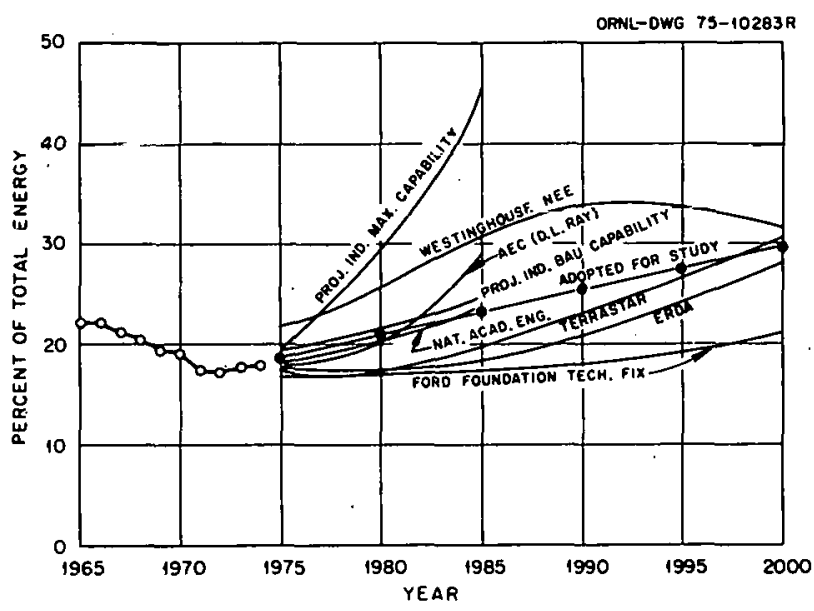

Fig. 3. Coal consumption as percentage of total energy.

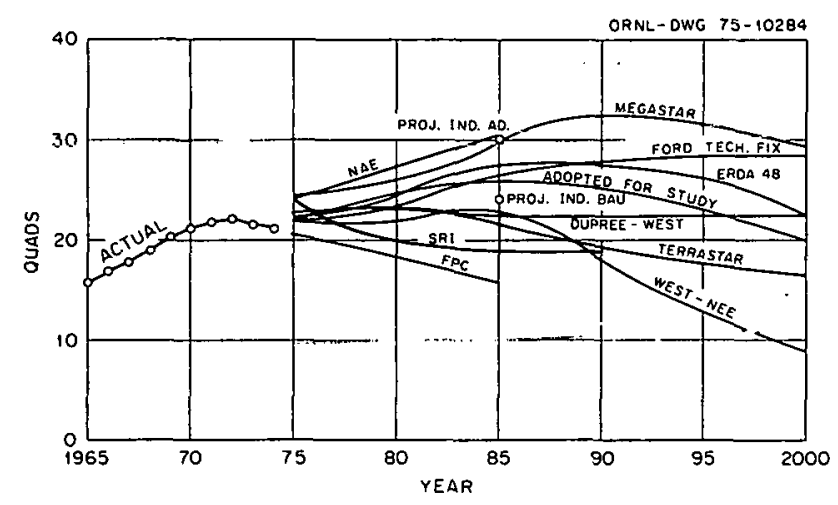

Fig. 4. Domestic natural gas production.

2000 and the remainder by 2010 . Using this same rcsource figure as a basis, the Project Independence estimate of an unconstrained accelerated development production of 20 million bbl/day (at $\$ 11$ per barrel) by $1985^{18}$ would lead to cxhaustion of domestic oil resources by the mid-1960s. The domestic oil production forecast selected for this study is given in Table 5 .
Table 5. Selected forecasts of domestic gas and oil production

\begin{tabular}{cccccc}
\hline Year & \multicolumn{2}{c}{$\begin{array}{c}\text { Natural gas } \\
\text { production }\end{array}$} & & \multicolumn{2}{c}{$\begin{array}{c}\text { Crude oil plus } \\
\text { natural gas liquids }\end{array}$} \\
\cline { 2 - 3 } \cline { 5 - 6 } \cline { 5 - 6 } & Quads & $\begin{array}{c}\text { Trillion cubic feet } \\
\text { per year }\end{array}$ & & Quads & $\begin{array}{c}\text { Millions of } \\
\text { barrels per day }\end{array}$ \\
\hline 1975 & 22.0 & 21.4 & & 22.0 & 10.4 \\
1980 & 24.5 & 23.8 & & 26.1 & 12.3 \\
1985 & 25.8 & 25.0 & & 28.0 & 13.2 \\
1990 & 25.0 & 24.3 & & 27.0 & 12.7 \\
1995 & 23.0 & 22.3 & & 23.0 & 10.9 \\
2000 & 20.0 & 19.4 & & 17.6 & 8.3 \\
\hline
\end{tabular}

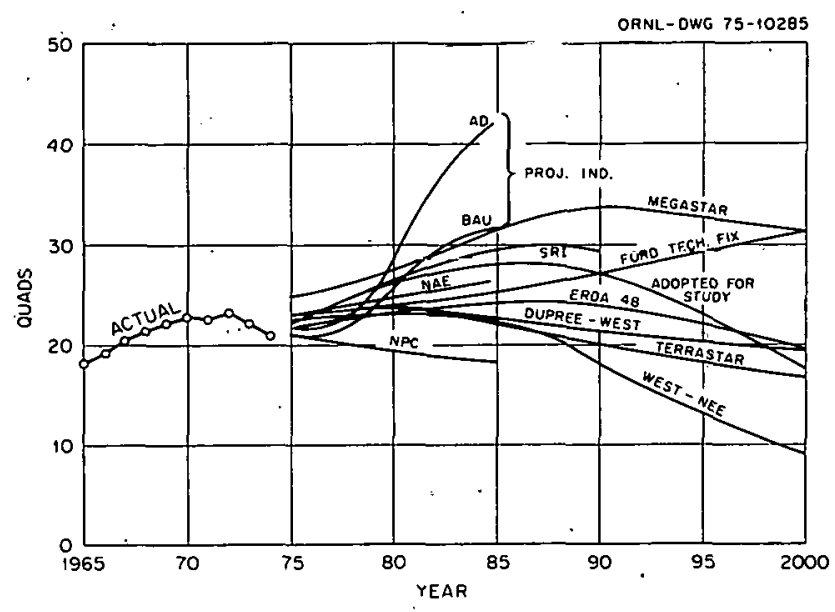

Fig. 5. Forecasts of domestic oil production (including natural gas liquids).

\subsection{Nuclear Power}

Because the contribution of nuclear power is likely to be almost entirely in the electrical sector, ORNL/TM5370 covers the devclopment of a nuclear power forecast. $^{26}$ This development projects an installed nuclear capacity of $700 \mathrm{GW}(\mathrm{e})$ in the year 2000 , which corresponds to a thermal generation of 43.7 quads in that year.

\subsection{Hydroelectric Power}

Hydroclectic power is also covered in ORNL/TM$5370 .^{26}$ An average of recent forecasts indicates that hydroclcctric generation might level off at 410 billinn $\mathrm{kWhr}$ by the year 2000 . The fuel equivalent of this generation at $33 \%$ efficiency would be 4.2 quads.

26. J. A. Lane, Electricity Consensus Forecast of Supply and Demand to the Year 2000, ORNL/TM-5370 (to be published). 


\subsection{Solar Energy}

Forecasts of the possible contribution of various applications of solar energy to the U.S. energy supply system in the year 2000 are given in Table 6 . Applications other than thermal electricity generation and photovoltaic central station plants are shown for purposes of comparison. Only forecasts made during the past $2 \frac{1 / 2}{2}$ years are included since prior energy: supply projections, such as those made by the Bureau of Mines ${ }^{27}$ or by the Department of the Interior, ${ }^{4}$ made no mention of solar energy. Although most of the forecasters gave projections for 1985 , the projections in general indicated a small or negligible contribution of solar energy in that year. Some of the forecasters projected a large contribution by solar energy by the years 2020-2025 (115 to 144 quads). The most important aspect of the data in Table 6 is the extremely wide range of the forecasts, which vary from 1 quad in the year 2000 to 94 quads (1.25 times present total U.S. energy consumption). For this reason the data are not suitable as a basis for a consensus-type projection. In the absence of a clear picture of the competitive position of solar electric plants, any forecast of the future contribution of such plants is pure conjecture.

As a guess, one might say that the contribution of solar plants (thermal electric and photovoltaic) in the year 2000 could reach an installed peak output of 10 GW(e) $\left[10^{7} \mathrm{~kW}(\mathrm{e})\right]$, assuming an economic breakthrough. Such plants would operate at an average plant factor of about $31 \%$ and generate about $2.7 \times 10^{10}$ $k W h r$ of electricity per year. The fuel equivalent of this electricity is about 0.3 quad.
With regard to wind-generated electricity, if one excludes the offshore applications because of technical and cost uncertainties and the Aleutian arc because of its remoteness, the wind potential (over the Great Plains) would be reduced to $210 \times 10^{9} \mathrm{kWhr}$ [80 $\mathrm{GW}(\mathrm{e})]$, or approximately 2 quads equivalent. A reasonable upper limit to the utilization of this source of energy appears to be not more than 1 quad by the year 2000 .

Other applications of solar energy, such as the heating and cooling of buildings, might contribute on the order of 2.5 quads by the year 2000. This would be equivalent to supplying $70 \%$ of the energy requirements of 20 million residential units.

\subsection{Geothermal}

Estimates of the rate of expansion of the U.S. geothermal power industry vary over wide limits. For example, Rex and Howell judge that " $40,000 \mathrm{MWe}$ of geothermal capacity could be discovered and developed in the Western United States in 20 years by the resource industry." 10 Their projection is based on the assumption that hot dry rock systems are technically and economically exploitable. The Hickel Panel in $1972^{28}$

27. W. E. Morrison and C. L. Readling, "An Energy Model for the U.S. Featuring Energy Balances for the Years 1947 to 1965 and Projections and Forecasts to the Years 1980 and 2000," Bureau of Mines Infomation Circular, IC-8384, July 1968.

28. U.S. Senate, Committee on Interior and Insular Affairs, Hickel Panel statement, $2 d$ session on the role of geothermal energy resources and research, June 15 and 22, 1972.

Table 6. Forecasts of solar energy applications in the year 2000

\begin{tabular}{|c|c|c|c|c|c|}
\hline & & In quads & & & \\
\hline Forecaster & $\begin{array}{l}\text { Date of } \\
\text { forecast }\end{array}$ & $\begin{array}{l}\text { Thermal } \\
\text { photovoltaic } \\
\text { electricity }\end{array}$ & $\begin{array}{l}\text { Wind and } \\
\text { ocean thermal } \\
\text { gradient }\end{array}$ & $\begin{array}{c}\text { Other } \\
\text { solar }\end{array}$ & Total \\
\hline NSF/NASA & Dec. 1972 & 3.1 & 2.4 & 6.5 & 12.0 \\
\hline NASA/ASEE TERRASTAR & Sept. 1973 & 0 & 0 & $3.5-6.1$ & $3.5-6.1$ \\
\hline Subpanel IX & Nov. 1973 & 5.3 & 15 & 4.5 & 24.8 \\
\hline Mitre Corporation & Dec. 1973 & $7-18$ & $11-27$ & 18 & $36-63$ \\
\hline Council on Environmental Quality & Mar. 1974 & 0 & 0 & 1 & 1 \\
\hline Ford Foundation & Late 1974 & 1 & 1 & 2 & 4 \\
\hline Project Independence Task Force & Nov. 1974 & $6-27$ & $19-40$ & $8-27$ & $34-94$ \\
\hline Institute for Energy Analysis & Jan. 1975 & $0-1.7$ & 0 & 0.2 & $0.2-1.9$ \\
\hline E. Teller & Apr. 1975 & 0 & 0 & 5 & 5 \\
\hline ERDA-48 & June 1975 & $1.3-6.1$ & 0 & 5 & $6.3-11.1$ \\
\hline ERDA-49 & June 1975 & 3.1 & 1.8 & 6 & 10.9 \\
\hline Hudson Institute & Aug. 1975 & $6-9$ & $6-9$ & $6-9$ & $18-27$ \\
\hline
\end{tabular}


was also very optimistic about the future of geothermal energy and projected an installed geothermal capacity of $395,000 \mathrm{MW}(\mathrm{e})$ by the year 2000 with an accelerated research program. ${ }^{28}$ More recent projections, shown in Table 7 , are considerably more conservative. These indicate that the geothermal capacity in the United States might reach about $8600 \mathrm{MW}(\mathrm{e})$ by 1985 and about $43,000 \mathrm{MW}(\mathrm{e})$ by the year. 2000. Assuming a central station efficiency comparable to that of nuclear and fossil-fueled plants, these installed capacities would contribute 0.6 and 3.0 quads in 1985 and 2000 respectively.

\subsection{Wood and Waste Materials}

Few forecasts of the future contribution of wood and waste materials were available for evaluation. Since the total energy generation from these sources will be relatively small, one can project a linear growth reaching a level equal to that of wood in the early 1950s. This results in a contribution of 1.1 quads by the year 2000 .

\subsection{Summary of U.S. Energy Consumption by Source}

The selected forecasts of energy consumption for each of the alternative sources of energy are summarized in Table 8 . The total contribution of these sources provides an indication of a consensus-type U.S. energy supply forecast. One can now subtract this energy supply from the overall energy demand forecast given in Table 2 to obtain an indication of the future requirements for imported oil under conditions of enhanced coal production, reasonable conservation, and the most likely contribution of the remaining domestic energy sources. Under the assumed conditions, selfsufficiency will not be reached until late in the century; however, oil imports will be reduced to manageable proportions by about 1985 .

\section{ENERGY USE BY CONSUMING SECTOR}

\subsection{Reference System}

Table 9 summarizes the U.S. energy supply and demand system for 1972. Figure 6 shows a flowsheet of energy supply to end use based on the data in Table 9. The reference consuming sectors in 1972 had the following levels of demand:

\footnotetext{
Residential

$66.7 \times 10^{6}$ households $\left(208.8 \times 10^{6}\right.$ population $)$ space heating $-48.8 \times 10^{6}$ Btu/unit air conditioning $-21.7 \times 10^{6} \mathrm{Btu} / \mathrm{unit}$ ( $38 \%$ of saturation) water heating and cooking $-23 \times 10^{6} \mathrm{Btu} / \mathrm{unit}$ miscellaneous electric $-4235 \mathrm{kWhr} / \mathrm{unit}\left(14.5 \times 10^{6}\right.$ Btu/unit)
}

Table 7. Furecasts of geothermal contribution to U.S. energy supply

\begin{tabular}{|c|c|c|c|c|c|}
\hline \multirow{2}{*}{ Forecaster } & \multirow{2}{*}{$\begin{array}{l}\text { Date of } \\
\text { forecast }\end{array}$} & \multicolumn{4}{|c|}{ Forecast geothermal contribution (quads) ${ }^{a}$} \\
\hline & & 1980 & 1985 & 1990 & 2000 \\
\hline Hickel Panel & June 1972 & $07-2,4$ & $1.3-8.8$ & $2.3-16.1$ & $5.0-26.3$ \\
\hline National Pelruleum Council & Dec. 1972 & 0.3 & 0.5 & & \\
\hline Stanford Research Institute & May 1973 & & 0.3 & & \\
\hline NASA/ASEE TERRASTAR & Sept. 1973 & 0.3 & 0.6 & & 2.5 \\
\hline U.S. Bureau of Mines & Oct. 19.73 & & 0.3 & & 2.7 \\
\hline $\begin{array}{l}\text { U.S. Atomic Energy Commission } \\
\text { (D. L. Ray) }\end{array}$ & Dec. 1973 & & 1.5 & & 6.0 \\
\hline Council on Environmental Quality & Mar. 1974 & & & & 2.0 \\
\hline National Academy of Engineering & May 1974 & & 0.5 & & $:$ \\
\hline NASA/ASEE MEGASTAR & Sept. 1974 & 0.1 & 0.2 & 0.3 & 0.5 \\
\hline Project Independence Task Force & Nov. 1974 & 0.06 & $0.3-2.3$ & $3.9-7.4$ & \\
\hline Ford Foundation & 1974 & & 1.0 & & 2.0 \\
\hline ERDA-48 & June 1975 & & $0.3-1.4$ & & $0.7-7.0$ \\
\hline E. H. Willis (ERDA) & Oct. 1975 & & 0.5 & & 4.1 \\
\hline Average $^{b}$ & & & 0.6 & & 3.0 \\
\hline
\end{tabular}

${ }^{a} \mathrm{MW}(\mathrm{e})$ converted to quads assuming $1000 \mathrm{MW}(\mathrm{e})=0.07$ quad.

${ }^{b}$ Excluding upper limit values. 
Table 8. Consensus forecast of U.S. future energy supply and demand

\begin{tabular}{lrrrrrr}
\hline \multicolumn{1}{c}{$\begin{array}{c}\text { Domestic supply by type } \\
\text { of energy source }\end{array}$} & \multicolumn{7}{c}{ Quads } \\
\cline { 2 - 7 } & 1975 & 1980 & 1985 & 1990 & 1995 & 2000 \\
\hline Coal & 13.2 & 18.7 & 23.3 & 28.3 & 33.8 & 39.9 \\
Natural gas & 20.2 & 24.5 & 25.8 & 25.0 & 23.0 & 20.0 \\
Domestic oil and natural gas liquids & 22.0 & 26.1 & 28.0 & 27.0 & 23.0 & 17.6 \\
Nuclear & 1.7 & 4.3 & 11.1 & 19.5 & 30.7 & 43.7 \\
Hydroelectric power & 3.1 & 3.4 & 3.7 & 3.9 & 4.1 & 4.2 \\
Solar electric & & & 0.2 & 0.4 & 0.7 & 1.0 \\
Solar heating and cooling & & 0.04 & 0.4 & 0.7 & 1.3 & 2.5 \\
Geothermal & 0.2 & 0.06 & 0.4 & 0.8 & 1.4 & 2.0 \\
Wood, biomass, and waste & 0.3 & 0.5 & 0.7 & 0.9 & 1.1 \\
$\quad$ Total domestic supply & 60.4 & 77.4 & 93.4 & 106.3 & 119.1 & 132.0 \\
Estimated domestic demand & & & & & & \\
Implied level of oil imports & 71.1 & 88.0 & 100.0 & 110.0 & 121.0 & 132.0 \\
\hline
\end{tabular}

${ }^{a}$ Based on conservation-oriented forecasts (Table 2); excludes 1.5 quads of coal exports. Data for 1975 are from the U.S. Bureau of Mines (preliminary as of Feb. 6, 1973).

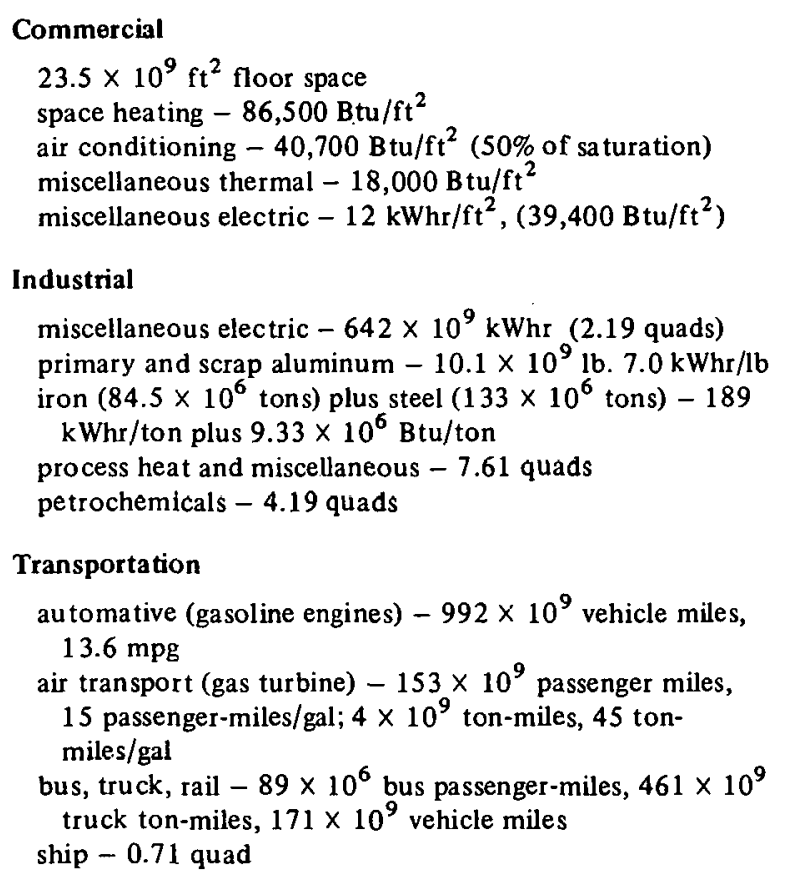

\subsection{Allocation of Losses to Consuming Sector}

The distribution of energy consumption in Table 9 treats energy losses incurred in generating electricity in refining oil and gas, and in producing coal as separate consuming sectors. In Table 10, these losses have been distributed to each sector in proportion to the amount consumed. Similarly, in Sect. 4.1, the differences in efficiency of using the various energy sources by the sector itself have not been taken into consideration.
Table 11 shows the distribution of end use consumption by source after allowing for differences in use efficiency. Table 12 summarizes the distribution of energy consumption by sector for both input and end use.

\subsection{Preliminary Energy Data for 1975}

Preliminary data on the distribution of energy consumption in 1975 by source and consuming sector were obtained from the U.S. Bureau of Mines ${ }^{29}$ and are given in Table 13. These data were matched to a supply and demand scenario using 1972 individual sector distributions of consumption as a basis. The results are shown in Tables 14 and 15.

\subsection{Forecast of Energy Consumption by Sector - Year 1985}

The distribution of energy consumption by consuming sector was assumed to be the same as that given in ERDA-48 Scenario $\mathrm{V} ;{ }^{30}$ however, the end use demands were increased $3 \%$ to adjust to the 1985 consensus forecast of 100 quads (see Table 2). The results are given in Table 16 .

29. C. E. Whittle, Institute for Energy Analysis, telephone call to C. Readling, Department of the Interior, Feb. 3, 1976.

30. Energy Research and Development Administration, $A$ National Plan for Energy Research, Development and Demonstration - Creating Energy Choices for the Future, ERDA-48, June 1975. 
Table 9. Summary of energy demand and fuel mix, 1972

In quads

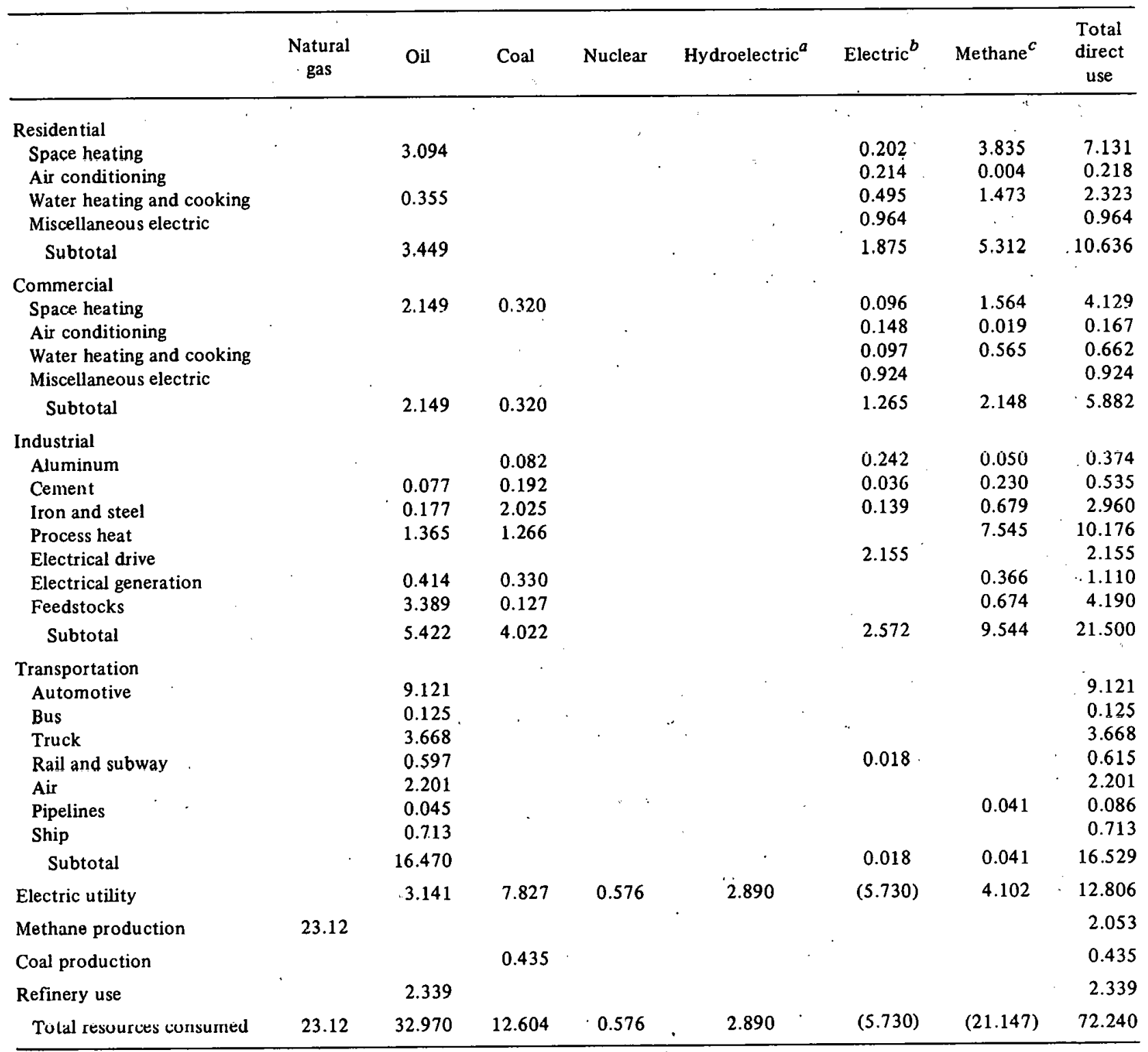

${ }^{a}$ Also includes geothermal. Hydroelectric power resource consumption is based on a conversion efficiency of $37 \%$; geothermal is based on a conversion efficiency of $15 \%$.

${ }^{b}$ Gives energy consumed as electricity at $3412.8 \mathrm{Btu} / \mathrm{kWhr}$. For fuels consumed in producing electricity, see row labeled "electric utility."

"Includes natural gas and gasified coal. Sce row labeled "methanc production."

Source: K. C. Hoftman et al., Current BNL Reference Energy System (KES) Projections, draft report, Brookhaven National Laboratory, Sept. 19, 1975. 


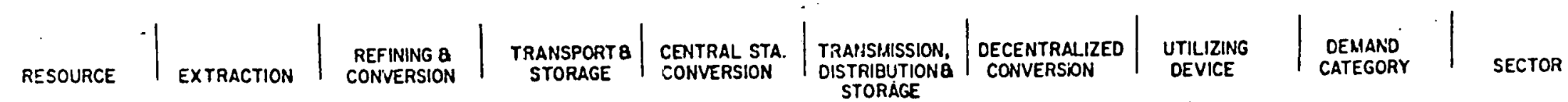

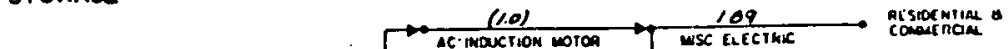

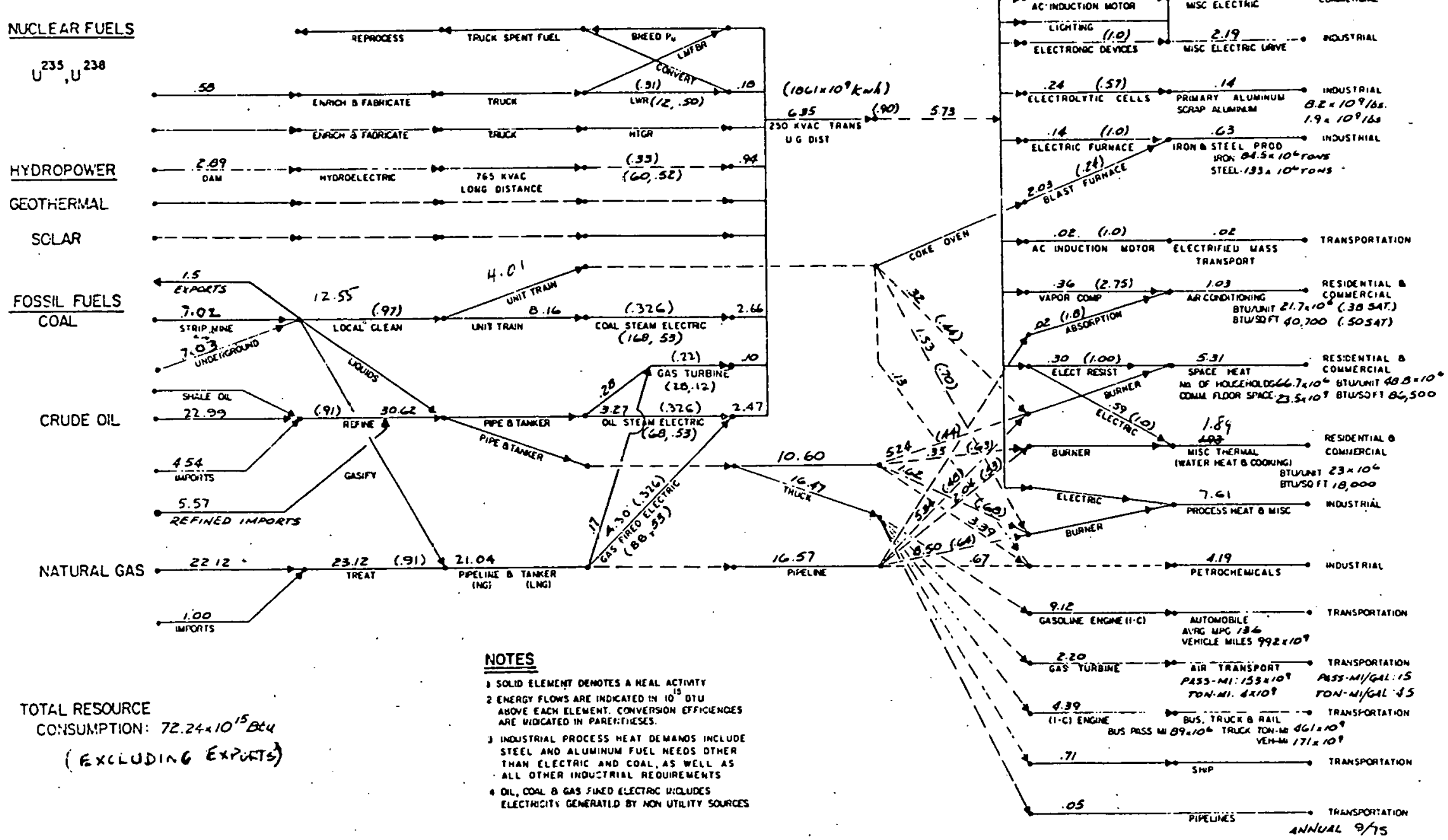

Fig. 6. Flowsheet for reference U.S. energy system (1972). Source: Associated Universities, Inc., Upton, L.I., New York 11973. 
Table 10. Summary of reference (1972) energy input by source.

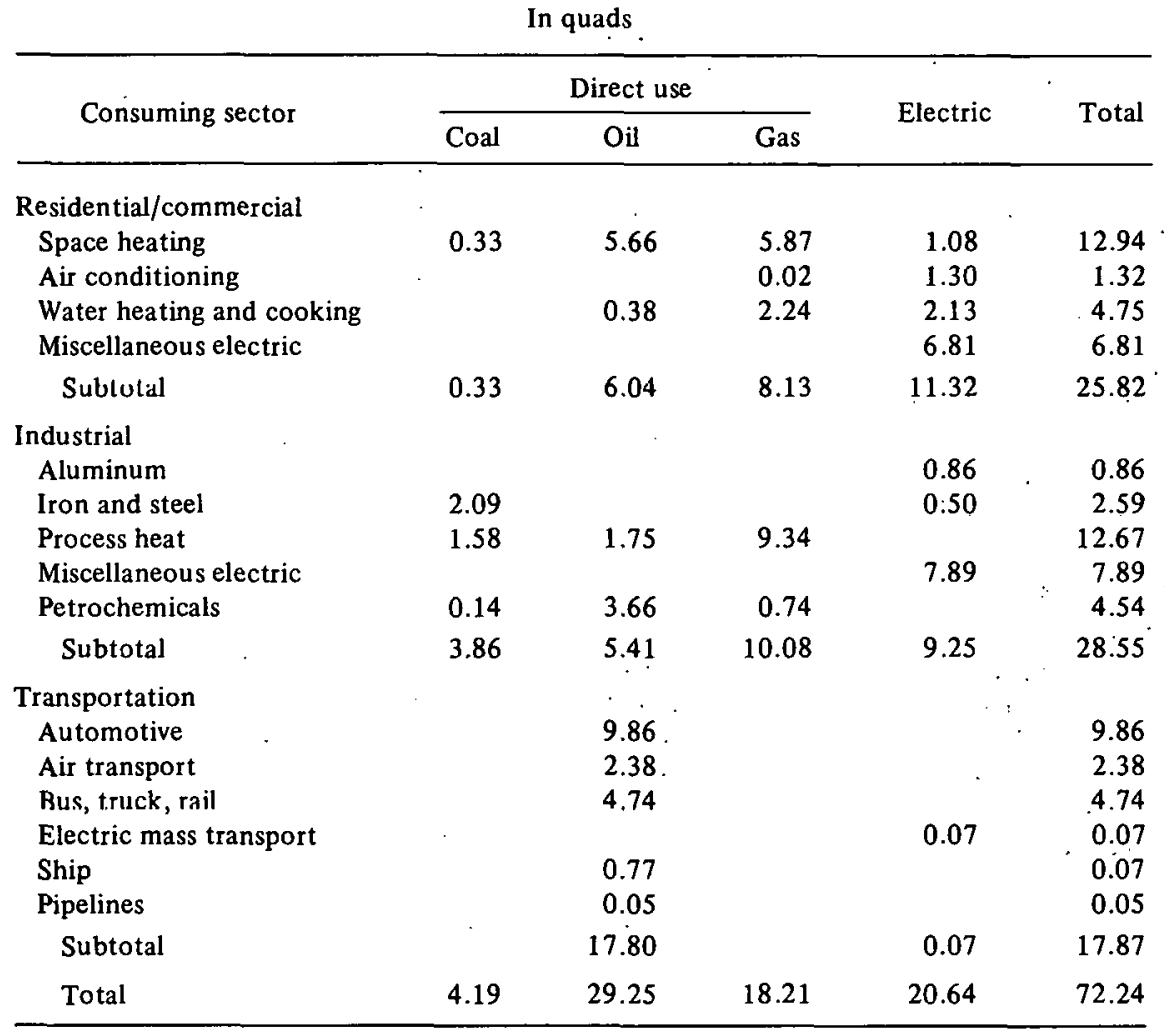

Table 11. Summary of reference (197.2) energy end use by source In quads

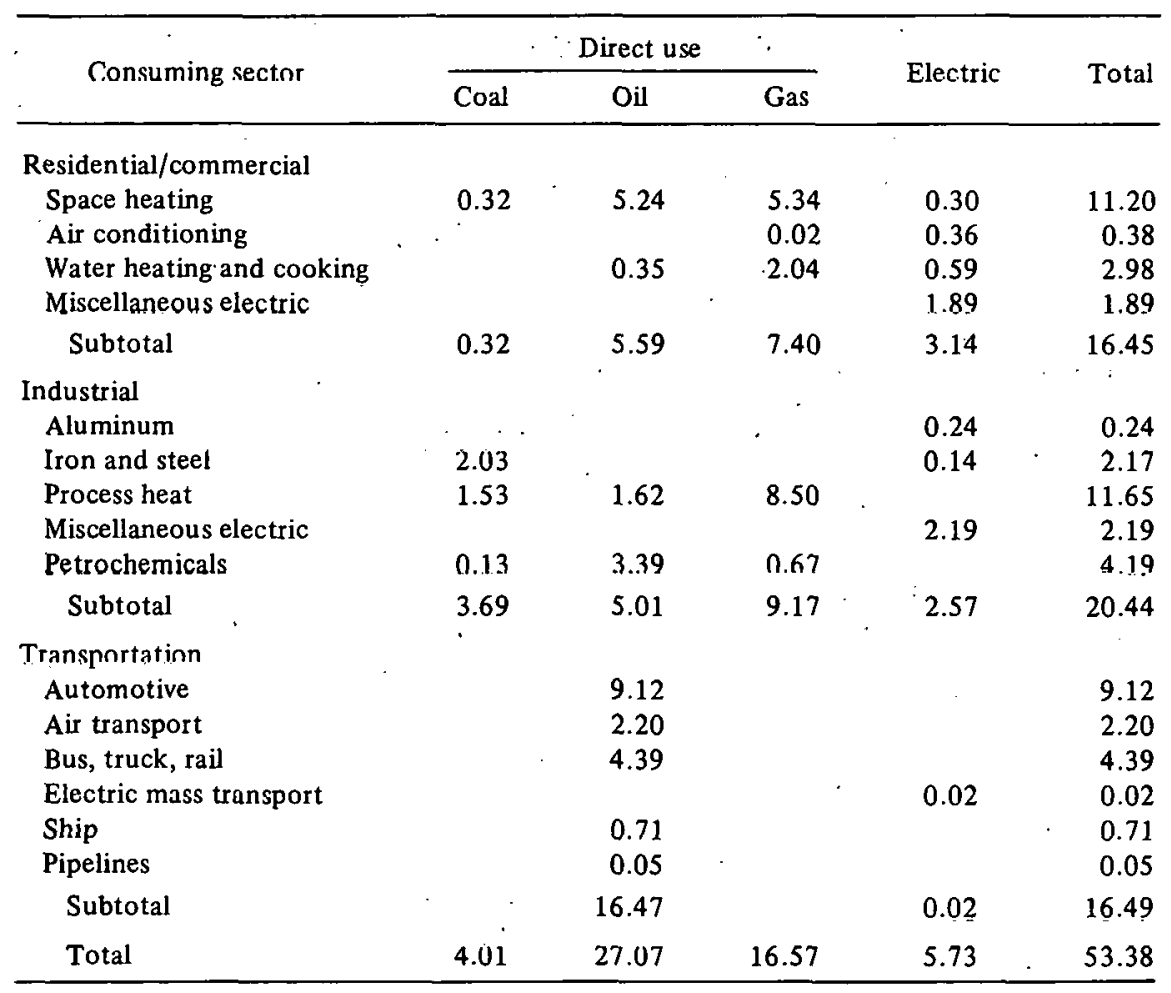


Table 12. Summary of reference (1972) energy system by consuming sector

\begin{tabular}{lcrrr}
\hline \multicolumn{1}{c}{ Consuming sector } & $\begin{array}{c}\text { Energy input } \\
\text { (quads) }\end{array}$ & $\begin{array}{c}\text { Percent of } \\
\text { total }\end{array}$ & $\begin{array}{c}\text { End use } \\
\text { (quads) }\end{array}$ & $\begin{array}{r}\text { Percent of } \\
\text { total }\end{array}$ \\
\hline Residential/commercial & & & & \\
Space heating & 12.94 & 17.9 & 11.20 & 21.0 \\
Air conditioning & 1.32 & 1.8 & 0.38 & 0.7 \\
Water heating and cooking & 4.75 & 6.6 & 2.98 & 5.6 \\
Miscellaneous electric & 6.81 & 9.4 & 1.89 & 3.5 \\
$\quad$ Subtotal & 25.82 & 35.7 & 16.45 & 30.8 \\
Industrial & & & & \\
Aluminum & 0.86 & 1.2 & 0.24 & 0.5 \\
Iron and steel & 2.09 & 2.9 & 2.17 & 4.1 \\
Process heat & 13.17 & 18.2 & 11.65 & 21.8 \\
Miscellaneous electric & 7.89 & 10.9 & 2.19 & 4.1 \\
Petrochemicals & 4.54 & 6.3 & 4.19 & 7.8 \\
Subtotal & 28.55 & 39.5 & 20.44 & 38.3 \\
Transportation & & & & \\
Automotive & 9.86 & 13.6 & 9.12 & 17.1 \\
Air transport & 2.38 & 3.2 & 2.20 & 4.1 \\
Bus, truck, rail & 4.74 & 6.6 & 4.39 & 8.2 \\
Electric mass transport & 0.07 & 0.1 & 0.02 & 0.1 \\
Ship & 0.77 & 1.1 & 0.71 & 1.3 \\
Pipelines & 0.05 & 0.1 & 0.05 & 0.1 \\
Subtotal & 17.87 & 24.7 & 16.49 & 30.9 \\
Total & 72.24 & 100.0 & 53.38 & 100.0 \\
\hline & & & & \\
\hline
\end{tabular}

Table 13. U.S. Bureau of Mines energy consumption data for 1975

In trillions of $\mathrm{Btu}^{a}$

\begin{tabular}{|c|c|c|c|c|c|c|c|c|c|}
\hline rnnsuming sector & Coal & $\begin{array}{c}\text { Natural } \\
\text { gas }\end{array}$ & Petroleum & Hydroelectric & Nuclear & $\begin{array}{l}\text { Gross } \\
\text { inpute }\end{array}$ & $\begin{array}{c}\text { Utility } \\
\text { electricity } \\
\text { distributed }\end{array}$ & $\underset{\text { elpertricity }}{\text { Gross }}$ & $\begin{array}{l}\text { Gross } \\
\text { inpulits }\end{array}$ \\
\hline Residential/Commercial & 282 & 7,373 & 5,829 & & & 13,484 & 3,783 & $(11,671)$ & 25,155 \\
\hline Industrial & 4,287 & 8,991 & 5,703 & 36 & & 19,017 & 2,708 & $(8,354)$ & 27,371 \\
\hline Transportation & 1 & 635 & 17,857 & & & 18,493 & 19 & $(59)$ & 18,552 \\
\hline Electric generation & 8,824 & 3,174 & 3,312 & 3,122 & 1,652 & 20,084 & & & \\
\hline Total & 13,394 & 20,173 & 32,701 & 3,158 & 1,652 & 71,078 & 6,510 & 20,084 & 71,078 \\
\hline
\end{tabular}

${ }^{a}$ Estimates of consumption rates for nonutility industrial electricity are as follows: 1974 - hydroelectric power, $3,537.1 \times 10^{6} \mathrm{kWhr}$; fuels, $98,904.5 \times 10^{6} \mathrm{kWhr}$ 1975 - hydroelectric power, $3,460 \times 10^{6} \mathrm{kWhr}$; fuels, $81,000 \times 10^{6} \mathrm{kWhr}$.

${ }^{b}$ Numbers in parentheses are indirect energy inputs to the process of generating electricity for the consuming sector indicated.

\subsection{Year 2000 Energy Consumption by Consuming Sector and Source}

The forecast of energy consumption for the year 2000 was assumed to be the same as that in ERDA-48 Scenario $\mathrm{V}\left(99 \times 10^{6}\right.$ households, $42 \times 10^{9} \mathrm{ft}^{2}$ of commercial floor space, etc.). These demands, however, were matched against the previously derived forecasts of energy supply by source (see Table 8 ) and against the electricity generation forecast given in ref. 31. End use demands were also adjusted for differences in utilization efficiencies of fuels and electricity. Table 17 shows the resulting distribution of energy consumption by end use. The corresponding distribution of energy inputs (including production losses) is shown in Table 18.

31. Ref. 26, Table 1. 
Table 14. Summary of 1975 energy input by source .

In quads

\begin{tabular}{|c|c|c|c|c|c|c|}
\hline Consuming sector & Coal & Oil & Gas & $\begin{array}{l}\text { Utility } \\
\text { electricity }\end{array}$ & $\begin{array}{l}\text { Industrial } \\
\text { electricity }\end{array}$ & Total \\
\hline \multicolumn{7}{|l|}{ Residential/commercial } \\
\hline Space heating & 0.28 & 5.46 & 5.32 & 1.12 & . & 12.18 \\
\hline Air conditioning & & & 0.02 & 1.33 & - & 1.35 \\
\hline Water heating and cooking & & 0.37 & 2.03 & - 2.14 & & 4.54 \\
\hline Miscellaneous electric & & & & 7.08 & $\cdot$ & 7.08 \\
\hline Subtotal & 0.28 & 5.83 & 7.37 & 11.67 & & 25.15 \\
\hline \multicolumn{7}{|l|}{ Industrial } \\
\hline Aluminum & & & & 0.78 & & 0.78 \\
\hline Iron and steel & 2.36 & & & 0.44 & & 2.80 \\
\hline Process heat & 1.65 & 1.71 & 7.74 & 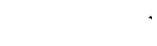 & 0.84 & 11.94 \\
\hline Miscellaneous electric & & & & 7.13 & 0.04 & 7.17 \\
\hline Petrochemicals & 0.16 & 3.86 & 0.66 & & & 4.68 \\
\hline Subtotal & 4.17 & 5.57 & 8.40 & 8.35 & 0.88 & 27.37 \\
\hline \multicolumn{7}{|l|}{ Transportation } \\
\hline Automotive & & 9.90 & & & $\cdot$ & 9.80 \\
\hline Air transport & & 2.38 & $\cdot$ & & $\cdot$ & 2.38 \\
\hline Bus, truck, rail & & 4.76 & & & . & 4.76 \\
\hline Electric mass transport & & & & 0.06 & & 0.06 \\
\hline Ship & & 0.77 & 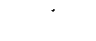 & & & 0.77 \\
\hline Pipelines & & 0.05 & 0.64 & & & 0.69 \\
\hline Subtotal & 0.00 & 17.86 & 0.64 & 0.06 & & 18.56 \\
\hline Total & 4.45 & 29.26 & 16.41 & 20.08 & 0.88 & 71.08 \\
\hline
\end{tabular}

Table 15. Summary of 1975 energy end use by source

In quads

\begin{tabular}{|c|c|c|c|c|c|}
\hline Consuming sector & Coal & Oil & Gas & Electric & Total \\
\hline \multicolumn{6}{|l|}{ Rcsidential/coinumercial } \\
\hline Space heating & 0.27 & 5.07 & 4.99 & 0.33 & 10.66 \\
\hline Air conditioning & & & 0.02 & 0.39 & 0.41 \\
\hline Water heating and cooking & & 0.34 & 1.90 & 0.64 & 2.88 \\
\hline Misćellaneous electric & & & & 2.07 & 2.07 \\
\hline Subtotal & 027 & 5.41 & 6.91 & 3.43 & 16.02 \\
\hline \multicolumn{6}{|l|}{ Industrial } \\
\hline Aluminum & & & & 0.23 & 0.23 \\
\hline Iron and steel & 2.29 & & & 0.13 & 2.42 \\
\hline Process heat & 1.57 & 1.63 & 7.36 & 0.80 & 11.36 \\
\hline Miscellaneous electric & & & & 2.11 & 2.11 \\
\hline Petrochemicals & 0.15 & 3.58 & 0.63 & & .4 .36 \\
\hline Subtotal & 4.01 & 5.21 & 7.99 & 3.27 & 20.48 \\
\hline \multicolumn{6}{|l|}{ Transportation } \\
\hline Automotive & & 9.18 & & & 9.18 \\
\hline Air transpnort & & 2.21 & & & 2.21 \\
\hline Bus, truck, rail & & 4.41 & & & 4.41 \\
\hline Electric mass transport & & & & 0.02 & 0.02 \\
\hline Ship & & 0.71 & & & 0.71 \\
\hline Pipelines & & 0.63 & & . & 0.63 \\
\hline Subtotal & & 17.14 & & 0.02 & 17.16 \\
\hline Total & 4.28 & 27.76 & 14.90 & 6.72 & 53.66 \\
\hline
\end{tabular}


Table 16. Summary of 1985 energy consumption by sector

\begin{tabular}{lrrrr}
\hline Consuming sector & $\begin{array}{c}\text { Energy input } \\
\text { (quads) }\end{array}$ & $\begin{array}{c}\text { Percent of } \\
\text { total }\end{array}$ & $\begin{array}{c}\text { End use } \\
\text { (quads) }\end{array}$ & $\begin{array}{r}\text { Percent of } \\
\text { total }\end{array}$ \\
\hline Residential/commercial & & & & \\
Space heating & 13.1 & 13.1 & 5.6 & 9.5 \\
Air conditioning & 2.9 & 2.9 & 2.7 & 4.6 \\
Water heating and cooking & 6.0 & 6.0 & 2.5 & 4.3 \\
Miscellaneous electric & 9.1 & 9.1 & 2.6 & 4.4 \\
$\quad$ Subtotal & 31.1 & 31.1 & 13.4 & 22.8 \\
Industrial & & & & \\
Aluminum & 1.6 & 1.6 & 0.3 & 0.5 \\
Iron and steel & 3.7 & 3.7 & 0.9 & 1.5 \\
Process heat & 18.9 & 18.9 & 11.7 & 19.9 \\
Miscellaneous electric & 11.9 & 11.9 & 3.4 & 5.8 \\
Petrochemicals & 8.6 & 8.6 & 7.8 & 13.2 \\
$\quad$ Subtotal & 44.7 & 44.7 & 24.1 & 40.9 \\
Transportation & & & & \\
Automotive & 11.3 & 11.3 & 10.3 & .17 .0 \\
Air transport & 6.0 & 6.0 & 5.5 & 9.3 \\
Bus, truck, rail & 4.8 & 4.8 & 4.4 & 7.5 \\
Electric mass transport & 0.6 & 0.6 & 0.2 & 0.3 \\
Ship & 1.4 & 1.4 & 1.2 & 2.0 \\
Pipelines & 0.1 & 0.1 & 0.1 & 0.2 \\
Subtotal & 24.2 & 24.2 & 21.4 & 36.3 \\
Total & 100.0 & 100.0 & 58.9 & 100.0 \\
\hline
\end{tabular}

Table 17. Forecast of energy end use consumption by source for the year $\mathbf{2 0 0 0}$

In quads

\begin{tabular}{|c|c|c|c|c|c|c|}
\hline Consuming sector & $\begin{array}{c}\text { Solar, } \\
\text { geothermal, and } \\
\text { waste heat }\end{array}$ & Coal & Oil & Gas & Electric & Total \\
\hline \multicolumn{7}{|l|}{ Residential/commercial } \\
\hline Space heating & 1.0 & & & 5.11 & 2.48 & 8.59 \\
\hline Air conditioning & & & & & 1.65 & 1.65 \\
\hline Water heating and cooking & 1.0 & & & 0.97 & 1.37 & 3.34 \\
\hline Miscellaneous electric & & & & & 3.10 & 3.10 \\
\hline Subtotal & 2.0 & & & 6.08 & 8.60 & 16.68 \\
\hline \multicolumn{7}{|l|}{ Industrial } \\
\hline Aluminum & & & & & 0.75 & 0.75 \\
\hline Iron and steel & & 2.14 & & & 0.32 & 2.46 \\
\hline Process heat & 4.3 & 10.17 & & 1.51 & 2.96 & 18.94 \\
\hline Miscellancous electric & & & & & 6.10 & 6.10 \\
\hline Petrochemicals & & 0.78 & & 10.25 & & 11.03 \\
\hline Subtotal & 4.3 & 13.09 & & 11.76 & 10.13 & 39.28 \\
\hline \multicolumn{7}{|l|}{ Transportation } \\
\hline Automotive & & & 8.15 & & 0.64 & 8.79 \\
\hline Air transport & . & & 7.33 & & & 7.33 \\
\hline Bus, truck, rail & & & 7.13 & & & 7.13 \\
\hline Electric mass transport & & & & & 0.23 & 0.23 \\
\hline Ship & & & 1.62 & & & 1.62 \\
\hline Pipelines & & & 0.20 & 0.35 & & 0.55 \\
\hline Subtotal & & & 24.43 & 0.35 & 0.87 & 25.65 \\
\hline Total & 6.3 & 13.09 & 24.43 & 18.19 & 19.60 & 81.61 \\
\hline
\end{tabular}


Table 18. Forecast of energy input by source for the year 2000

In quads

\begin{tabular}{|c|c|c|c|c|c|c|}
\hline Consuming sector & $\begin{array}{l}\text { Solar and } \\
\text { geothermal }\end{array}$ & . Coal & Oil & Gas & Electric & Total \\
\hline \multicolumn{7}{|l|}{ Residential/commercial } \\
\hline Space heating & 0.6 & & & 5.5 & 8.3 & $\therefore \quad 14.4$ \\
\hline Air conditioning & & & & & 5.5 & 5.5 \\
\hline Water heating and cooking & 0.6 & & & 1.1 & 4.2 & 5.9 \\
\hline Miscellaneous electric & & & & & 10.2 & 10.2 \\
\hline Subtotal & 1.2 & & & 6.6 & 28.2 & 36.0 \\
\hline Industrial & & & & & $\cdot$ & . \\
\hline Aluminum & & & & & 2.6 & 2.6 \\
\hline Iron and steel & & 2.2 & & & 1.0 & 3.2 \\
\hline Process heat & 2.3 & $10.5^{\circ}$ & & 1.6 & $9.9^{\circ}$ & 24.3 \\
\hline Miscellaneous electric & & & & & 20.1 & 20.1 \\
\hline Petrochemicals & & 1.1 & & .11 .4 & & 12.5 \\
\hline Subtotal & 2.3 & 13.8 & & 13.0 & 33.6 & 62.7 \\
\hline Transportation & & & & & $\therefore$ & \\
\hline Automotive & & 4.3 & 5.9 & & $2: 0$ & 12.2 \\
\hline Air transport & $\cdot$ & $3.8^{\circ}$ & 5.3 & & $\cdot$. & 9.1 \\
\hline Bus, truck, rail & & 3.7 & 5.1 & & & 8.8 \\
\hline Electric mass transport & & & & & 0.60 & 0.6 \\
\hline Ship & & 0.8 & 1.2 & & & 2.0 \\
\hline Pipelines & $\cdot$ & 0.1 & 0.1 & 0.4 & . & 0.6 \\
\hline Subtotal & 0.0 & $12.7^{a}$ & 17.6 & 0.4 & 2.6 & 33.3 \\
\hline Total & 3.5 . & 26.5 & 17.6 & 20.0 & 64.4 & 132.0 \\
\hline
\end{tabular}

${ }^{a}$ Synthetic crude.

Table 19 gives the percentage distribution of energy input and end use consumption for the year 2000 .

\section{SUMMARY OF U.S. ENERGY RESOURCES}

\subsection{Coal}

The current estimate for total identified and hypothetical remaining U.S. coal is 3968 billion tons. ${ }^{32}$ If one deducts 388 billion tons of coal at depths greater than $3000 \mathrm{ft}$, eliminates $42 \%$ for thin seams less than 14 in., and assumes that $50 \%$ of the remainder is recoverable, the result is 1038 billion tons available for future use as needed. It is assumed here that only $60 \%$ of this amount ( 600 billion tons) will be recoverable in the next 50 years. More than one-third of the 600 billion tons is recoverable with current technology. Two recent publications ${ }^{33,34}$ on Alaska's abundant coal resources indicate that the amounts given here may not be sufficiently optimistic in the long run.

\subsection{Oil and Gas}

New data on the remaining recoverable U.S. oil and gas reserves have been published recenlly. ${ }^{25}$ These revised estimates have been made on the basis of a careful review of current geological sampling data. The results are given with $95 \%, 5 \%$, and mean probability estimates for total remaining recoverable oil and natural gas. These new estimates are given in Tables 20 and 21 .

\subsection{Shale Oil}

The estimates of shale oil by deposit, shown in Table 22 , have not changed since $1973 .^{35,36}$ Over 2000 billion bbl of oil is estimated to be in identified deposits of a grade of $10 \mathrm{gal} / \mathrm{ton}$ or higher. Assuming in-situ recovery at a $30 \%$ rate, the recoverable oil is estimated

32. P. Averitt, Coal Resources of the United States, January 1, 1974, U.S. Geological Survey Bulletin 1412, 1975.

33. D. L. McGee and K. M. O'Connor, Coal, Alaska Open File Report 51, April 1975.

34. I. L. Taillour and W. P. Brosge, Possible Order of Magnitude Increase in Coal Resources for Northern Alaska, U.S. Geological Survey draft report, April 1974.

35. W. C. Culbertson and J. K. Pitman, "Oil Shale," United States Mineral Resources, U.S. Geological Survey Professional Paper 820, 1973.

36. National Petroleum Council, Oil Shale Availability, U.S. Energy Outlusk, 1973. 
Tabie 19. Summary of energy consumption by consuming sector for the year $\mathbf{2 0 0 0}$

\begin{tabular}{|c|c|c|c|c|}
\hline Consuming sector & $\begin{array}{l}\text { Energy input } \\
\text { (quads) }\end{array}$ & $\begin{array}{l}\text { Percent of } \\
\text { total }\end{array}$ & $\begin{array}{l}\text { End use } \\
\text { (quads) }\end{array}$ & $\begin{array}{l}\text { Percent of } \\
\text { total }\end{array}$ \\
\hline \multicolumn{5}{|l|}{ Residential/commercial } \\
\hline Space heating & 14.4 & 10.9 & 8.6 & 10.6 \\
\hline Air conditioning & 5.5 & 4.2 & 1.7 & 2.1 \\
\hline Water heating and cooling & 5.9 & 4.5 & 3.3 & 4.0 \\
\hline Miscellaneous electric & 10.2 & 7.7 & 3.1 & 3.8 \\
\hline Subtotal & 36.0 & 27.3 & 16.7 & 20.5 \\
\hline \multicolumn{5}{|l|}{ Industrial } \\
\hline Aluminum & 2.6 & 2.0 & 0.8 & 1.0 \\
\hline Iron and steel & 3.2 & 2.4 & 2.5 & 3.1 \\
\hline Process heat & 24.3 & 18.4 & 18.9 & 23.1 \\
\hline Miscellaneous electric & 20.1 & 15.2 & 6.1 & 7.5 \\
\hline Petrochemicals & 12.5 & 9.5 & 11.0 & 13.4 \\
\hline Subtotal & 62.7 & 47.5 & 39.3 & 48.1 \\
\hline \multicolumn{5}{|l|}{ Transportation } \\
\hline Automotive & 12.2 & 9.2 & 8.9 & 10.9 \\
\hline Air transport & 9.1 & 6.9 & 7.3 & 9.0 \\
\hline Bus, truck, rail & 8.8 & 6.7 & 7.2 & 8.8 \\
\hline Electric mass transport & 0.6 & 0.4 & 0.2 & 0.2 \\
\hline Ship & 2.0 & 1.5 & 1.6 & 2.0 \\
\hline Pipelines & 0.6 & 0.5 & 0.5 & 0.6 \\
\hline Subtotal & 33.3 & 25.2 & 25.6 & 31.4 \\
\hline Total & 132.0 & 100.0 & 81.6 & 100.0 \\
\hline
\end{tabular}

Table 20. Current U.S. Geological Survey estimates of U.S. resources of crude oil and natural gas liquids

One barrel of liquid $=5.8 \times 10^{6} \mathrm{Btu}$

\begin{tabular}{|c|c|c|c|}
\hline & $\begin{array}{l}\text { Cluch vil } \\
\left(10^{6} \text { bul }\right)\end{array}$ & $\begin{array}{l}\text { Nalusal gas liquuidids } \\
\qquad\left(10^{6} \mathrm{bbl}\right)\end{array}$ & $\begin{array}{c}\text { Tutäl } \\
\left(10^{6} \mathrm{bbl}\right)\end{array}$ \\
\hline Cumulative production - Dec. 31,1974 & 106,136 & 15,730 & 121,866 \\
\hline \multicolumn{4}{|l|}{ Reserves } \\
\hline Measured & 34,250 & 6,350 & 40,600 \\
\hline Indicated & $4,636^{\circ}$ & NA & 4,636 \\
\hline Inferred & 23,100 & 6,000 & 29,100 \\
\hline \multicolumn{4}{|l|}{ Undiscovered recoverable } \\
\hline $95 \%$ probable & 50,000 & 11,000 & 61,000 \\
\hline Mean & 82,000 & 15,800 & 97,800 \\
\hline $5 \%$ probable & 127,000 & 22,000 & 149,000 \\
\hline \multicolumn{4}{|l|}{ Reserves plus undiscovered recoverable } \\
\hline $95 \%$ & 111,986 & 23,350 & 135,336 \\
\hline Mean & 143,986 & 28,150 & 172,136 \\
\hline $5 \%$ & 188,986 & 34,350 & 223,336 \\
\hline \multicolumn{4}{|l|}{ Total past and future production } \\
\hline $95 \%$ & 218,122 & 39,080 & $257,202^{a}$ \\
\hline Mean & 250,122 & 43,880 & $294,002^{b}$ \\
\hline $5 \%$ & 295,122 & 50,080 & $345,202^{c}$ \\
\hline
\end{tabular}

\footnotetext{
$a_{1,491 \text { quads. }}$

$b_{1,705}$ quads.

$c_{2,001}$ quads.
} 
Table 21. Current U.S. Geological Survey estimates of U.S. resources of natural gas (dry)

\begin{tabular}{lc}
\hline & Trillion cubic feet \\
\hline Cumulative production - Dec. 31,1974 & 480.824 \\
Measured reserves & 237.132 \\
$\quad$ Subtotal & 717.956 \\
Inferred reserves & 201.600 \\
Undiscovered recoverable & \\
$95 \%$ probable & 322 \\
Mean & 484 \\
$5 \%$ probable & 655 \\
Total past plus probable future production & \\
$95 \%$ & $1,242^{a}$ \\
Mean & $1,404^{b}$ \\
$5 \%$ & $1,575^{c}$ \\
\hline$a 1,280$ quads. & \\
${ }_{1} 1,447$ quads. & \\
${ }_{1,624}$ quads. &
\end{tabular}

here to be 600 billion bbl with 1 gal of water required for each gallon of oil recovered. The development of the most economical recovery technology for protecting the environment and minimizing the water requirements is needed.

\subsection{Uranium and Thorium}

The best estimates for uranium oxide $\left(\mathrm{U}_{3} \mathrm{O}_{8}\right)$ ore at a concentration greater than $1000 \mathrm{ppm}$ have been increased to 3.6 million tons. ${ }^{37}$ This represents a $50 \%$ increase over the previous estimates. The uranium reserve could still increase to 7.5 million tons in the

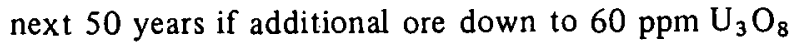
is included. Estimates for U.S. thorium resources are of the order of 150,000 tons of thorium dioxide $\left(\mathrm{ThO}_{2}\right)$ for ures containing more than $0.1 \% \mathrm{Th}_{1} \mathrm{O}_{2}$ or recover. able as a by-product. ${ }^{38}$

\subsection{Geothermal Heat}

New estimates for the U.S. geothermal resources were published recently in a U.S. Geological Survey bulletin. ${ }^{39}$ The total recoverable fuel equivalent of identified and inferred reserves is estimated to be 2000 quads. About one-half of this amount is from hydrothermal convection systems and the rest from geopressurized and other deeper rock systems. Table 23 gives a summary based on the recent report.

\subsection{Summary of Resource Estimates}

Table 24 gives a summary of the current estimates for the U.S. energy resources reviewed in the previous sections. These estimates need to be further evaluated and reviewed periodically; particular attention should be given to the economics of production and interfuel competition.

\section{LONG-TERM OUTLOOK FOR DOMESTIC FOSSIL FUEL SUPPLY}

\subsection{Coal}

If one considers the next 65 years as the long term, it is not likely that the use of coal to produce electricity, heat, or synthetic fuels will be limited by its unavailability (at competitive costs). Using the maximum

37. Energy Research and Development Administration, Report of the Liquid Metal Fast Breeder Reacior Program Review Group, ERDA-1 (January 1975); personal communication, National Uranium Resource Evaluation Program, December 1975.

38. W. I. Finch et al., "Nuclear Fuels," United States Mineral Resources, U.S. Geological Survey Professional Paper 820, 1973.

39. D. F. White and D. L. Williams, Assessment of Geothermal Resources of the United States - 1975, U.S. Geological Survey Circular 726, 1975.

Table 22. Shale-oil resources of the United States by grade

\begin{tabular}{|c|c|c|c|c|c|c|}
\hline \multirow{3}{*}{ Deposit } & \multicolumn{6}{|c|}{ Billions of barrels of oil by grade } \\
\hline & \multicolumn{2}{|c|}{ Identified } & \multicolumn{2}{|c|}{ Hypothetical } & \multicolumn{2}{|c|}{ Speculative } \\
\hline & $\begin{array}{l}25-100 \\
\mathrm{gal} / \text { ton }\end{array}$ & $\begin{array}{l}10-25 \\
\mathrm{gal} / \mathrm{ton}\end{array}$ & $\begin{array}{l}25-100 \\
\mathrm{gal} / \mathrm{ton}\end{array}$ & $\begin{array}{l}10-25 \\
\mathrm{gal} / \text { ton }\end{array}$ & $\begin{array}{l}25-100 \\
\mathrm{gal} / \mathrm{ton}\end{array}$ & $\begin{array}{l}10-25 \\
\mathrm{gal} / \mathrm{ton}\end{array}$ \\
\hline $\begin{array}{l}\text { Green River formation } \\
\text { (Colorado, Utah, and Wyoming) }\end{array}$ & 418 & 1400 & 50 & 600 & . & \\
\hline $\begin{array}{l}\text { Chattanooga shale } \\
\text { (central and eastern U.S.) }\end{array}$ & & 200 & & 800 & & \\
\hline Marine shale (Alaska) & & & 250 & 200 & & · \\
\hline Other deposits & & & & & 600 & 23,000 \\
\hline Total & 418 & 1600 & 300 & 1600 & 600 & 23,000 \\
\hline
\end{tabular}


Table 23. Geothermal resource estimates

\begin{tabular}{|c|c|c|c|c|c|c|}
\hline \multirow[b]{2}{*}{ Resource } & \multicolumn{2}{|c|}{ Identified } & \multicolumn{2}{|c|}{ Inferred } & \multicolumn{2}{|c|}{ Total } \\
\hline & $\begin{array}{c}\text { Electric or } \\
\text { heat }\end{array}$ & $\begin{array}{c}\text { Fuel } \\
\text { equivalent } \\
\text { (quads) }\end{array}$ & $\begin{array}{c}\text { Electric or } \\
\text { heat }\end{array}$ & $\begin{array}{c}\text { Fuel } \\
\text { equivalent } \\
\text { (quads) }\end{array}$ & $\begin{array}{c}\text { Electric or } \\
\text { heat }\end{array}$ & $\begin{array}{l}\text { Fuel } \\
\text { equivalent } \\
\text { (quads) }\end{array}$ \\
\hline \multicolumn{7}{|l|}{ Hydrothermal convection systems } \\
\hline$>150^{\circ} \mathrm{C}$ electric ${ }^{a}$ & $\begin{array}{l}7000 \\
\text { MW-centuries }\end{array}$ & 65.6 & $\begin{array}{l}23,000 \\
\text { MW-centuries }\end{array}$ & 216 & 30,000 & 282 \\
\hline $\begin{array}{l}\text { Hydrothermal } \\
>150^{\circ} \text { nonelectric }{ }^{b} \text { and } 90^{\circ} \text { to } 150^{\circ} \mathrm{C}\end{array}$ & 91 quads & 140 & 365 quads & 562 & 456 quads & 702 \\
\hline Geopressured systems plan 3 & & & 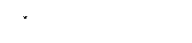 & & $\cdot$ & \\
\hline Electric ${ }^{a, c}$ & $\begin{array}{l}9250 \\
\text { MW-centuries }\end{array}$ & 87.5 & $\begin{array}{l}28,000 \\
\text { MW-centuries }\end{array}$ & 260 & $\begin{array}{l}37,000 \\
\text { MW-centuries }\end{array}$ & 350 \\
\hline \multicolumn{7}{|l|}{ Other } \\
\hline Hot dry and molten igenous rocks & 160 quads & & 480 quads & & & 640 \\
\hline
\end{tabular}

${ }^{a}$ Fuel equivalent for electric output was obtained by converting electrical estimates using an efficiency of 0.32 .

${ }^{b}$ Fuel equivalent for beneficial heat was obtained by converting heat estimates using an efficiency of 0.65 .

${ }^{c}$ These estimates do not include the heat content of methane in these systems.

Source: Based on an analysis of D. F. White and D. L. Williams, Assessment of Geothermal Resources of the United States 1975, U.S. Geological Survey Circular 726, 1975, by Gregg Marland of the Institute of Energy Analysis.

Table 24. Summary of recoverable resource estimates

\begin{tabular}{lccr}
\multicolumn{4}{c}{ In quads } \\
\hline Resource & $\begin{array}{c}\text { Demonstrated } \\
\text { reserves }\end{array}$ & $\begin{array}{c}\text { Estimated } \\
\text { additional }\end{array}$ & $\begin{array}{c}\text { Estimated } \\
\text { total }\end{array}$ \\
\hline Coal & 4800 & 7200 & 12,000 \\
Petroleum & 235 & 765 & 1,000 \\
Natural gas & 245 & 705 & 950 \\
Shale oil & 1160 & 2320 & 3,480 \\
Uranium & 1800 & 1800 & 3,600 \\
Geothermal & 200 & 1800 & 2,000 \\
\hline
\end{tabular}

scenario of the Institute of Energy Analysis as a basis, ${ }^{2}$ cumulative coal consumption would amount to about 10 billion tons by 1985,50 billion tons by 2000 , and 270 billion tons by 2040 . These amounts are well within the estimated domestic resources.

\subsection{Oil and Natural Gas}

The Institute of Energy Analysis (IEA) has projected the total use of domestic oil and natural gas by fitting Hubbert-type curves to U.S. Geological Survey resource estimates. ${ }^{40}$ Table 25 shows past production of these resources, and Table 26 shows the IEA estimates of future production. These results indicate that there is a 95\% probability that production of crude oil and natural gas liquids will peak in 1980 at 21.7 quads and that there is a $5 \%$ probability that the peak production
Table 25. Total annual U.S. production of crude oil, natural gas, and natural gas liquids

In quads

\begin{tabular}{lccc}
\hline Year & Total & $\begin{array}{c}\text { Crude oil and } \\
\text { natural gas liquids }\end{array}$ & Natural gas \\
\hline 1910 & 1.8 & 1.22 & 0.55 \\
1915 & 2.3 & 1.63 & 0.68 \\
1920 & 3.5 & 2.57 & 0.88 \\
1925 & 5.7 & 4.43 & 1.31 \\
1930 & 7.4 & 5.21 & 2.15 \\
1935 & 7.9 & 5.78 & 2.14 \\
1940 & 10.8 & 7.85 & 2.98 \\
1945 & 14.4 & 9.94 & 4.42 \\
1950 & 18.3 & 11.45 & 6.84 \\
1955 & 25.0 & 14.44 & 10.53 \\
1960 & 28.8 & 14.66 & 14.14 \\
1965 & 33.6 & 15.93 & 17.65 \\
1970 & 43.9 & 19.77 & 24.15 \\
1974 & 42.0 & 20.50 & 21.45 \\
\hline
\end{tabular}

will amount to 27.1 quads occurring in 1990. Similarly, the $95 \%$ probability for natural gas is a peak production of 26.3 quads in 1980 . The $5 \%$ probability case shows natural gas production peaking at 31.5 quads in 1985 . Production of both liquids and gases drops essentially to zero by 2040 .

40. C. E. Whittle, Institute for Energy Analysis, personal communication to J. A. Lane, Oak Ridge, Tenn., January 1976. 
Table 26. Projected U.S. production of crude oil, natural gas, and natural gas liquids

Projections were made using fitted Hubbert-type curves without explicit prices.

(In quads)

\begin{tabular}{lrrrrrrr}
\hline & \multicolumn{3}{c}{$\begin{array}{c}\text { Crude oil and } \\
\text { natural gas liquids }\end{array}$} & & \multicolumn{3}{c}{ Natural gas } \\
\cline { 2 - 5 } \cline { 6 - 8 } & $95 \%$ & Mean & $5 \%$ & & $95 \%$ & Mean & $5 \%$ \\
\hline 1980 & 21.7 & 23.8 & 25.9 & & 26.3 & 28.5 & 30.4 \\
1985 & 21.1 & 23.9 & 27.0 & & 25.2 & 28.5 & 31.5 \\
1990 & 19.7 & 23.2 & 27.1 & & 22.3 & 26.4 & 30.3 \\
2000 & 15.4 & 19.4 & 24.6 & & 14.2 & 18.4 & 22.8 \\
2010 & 10.6 & 14.3 & 19.5 & & 7.6 & 10.4 & 13.8 \\
2020 & 6.8 & 9.6 & 13.9 & & 3.6 & 5.3 & 7.3 \\
2030 & 4.1 & 6.1 & 9.2 & & 1.7 & 2.5 & 3.6 \\
2040 & 2.4 & 3.7 & 5.8 & 0.7 & 1.2 & 1.7 \\
\hline
\end{tabular}


THIS PAGE

WAS INTENTIONALLY

LEFT BLANK 
ORNL/TM-5369

Dist. Category UC-80

INTERNAL DISTRIBUTION

1. T. D. Anderson

2. S. E. Beall

3. C. C. Burwell

4. R. S. Carlsmith

5. F. L. Culler

6. W. Fulkerson

7-10. J. A. Lane

11-35. R. S. Livingston
36. J. W. Michel

37. M. W. Rosenthal

38-40. Central Research Library

41. Document Refcrence Section

42-43. Laboratory Records

44. Laboratory Records, ORNL RC

45. ORNL Patent Office

46-48. ORNL Technical Publications Department

EXTERNAL DISTRIBUTION

49-50. ORAU-IEA

51. Director, Research and Technical Support Division, ERDA-ORO

52. Director, Reactor Division, ERDA-ORO

53-54. Director, Division of Reactor Research and Development, ERDA, Washington, D.C. 20014

55-194. Given distribution as shown in TID 4500 under General Reactor Technology category (2.5 copies - NTIS) 